Louisiana State University

LSU Digital Commons

1982

\title{
Cardiovascular Responses in High, Moderate and Low Aerobic Capacity Males During Static and Dynamic Work.
}

John Francis Harper

Louisiana State University and Agricultural \& Mechanical College

Follow this and additional works at: https://digitalcommons.Isu.edu/gradschool_disstheses

\section{Recommended Citation}

Harper, John Francis, "Cardiovascular Responses in High, Moderate and Low Aerobic Capacity Males During Static and Dynamic Work." (1982). LSU Historical Dissertations and Theses. 3760.

https://digitalcommons.Isu.edu/gradschool_disstheses/3760

This Dissertation is brought to you for free and open access by the Graduate School at LSU Digital Commons. It has been accepted for inclusion in LSU Historical Dissertations and Theses by an authorized administrator of LSU Digital Commons. For more information, please contact gradetd@lsu.edu. 


\section{INFORMATION TO USERS}

This reproduction was made from a copy of a document sent to us for microfilming. While the most advanced technology has been used to photograph and reproduce this document, the quality of the reproduction is heavily dependent upon the quality of the material submitted.

The following explanation of techniques is provided to help clarify markings or notations which may appear on this reproduction.

1. The sign or "target" for pages apparently lacking from the document photographed is "Missing Page(s)". If it was possible to obtain the missing page(s) or section, they are spliced into the film along with adjacent pages. This may have necessitated cutting through an image and duplicating adjacent pages to assure complete continuity.

2. When an image on the film is obliterated with a round black mark, it is an indication of either blurred copy because of movement during exposure, duplicate copy, or copyrighted materials that should not have been filmed. For blurred pages, a good image of the page can be found in the adjacent frame. If copyrighted materials were deleted, a target note will appear listing the pages in the adjacent frame.

3. When a map, drawing or chart, etc., is part of the material being photographed, a definite method of "sectioning" the material has been followed. It is customary to begin filming at the upper left hand comer of a large sheet and to continue from left to right in equal sections with small overlaps. If necessary, sectioning is continued again-beginning below the first row and continuing on until complete.

4. For illustrations that cannot be satisfactorily reproduced by xerographic means, photographic prints can be purchased at additional cost and inserted into your xerographic copy. These prints are available upon request from the Dissertations Customer Services Department.

5. Some pages in any document may have indistinct print. In all cases the best available copy has been filmed.

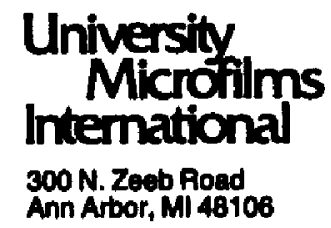


Haper, John Francis

CARDIOVASCULAR RESPONSES IN HIGH, MODERATE AND LOW AEROBIC CAPACITY MALES DURNG STATIC AND DYNAMIC WORK

The Louisiana State Universily and Agricultural and Mechanical CoL PH.D. 1982

\author{
University \\ Microfilms \\ International 300 N. Zeeb Road, Ann Arbor, MI 48106
}


CARDIOVASCULAR RESPONSES IN HIGH, MODERATE AND LON AEROBIC

CAPACITY MALES DURING STATIC AND DYNAMIC WORK

\section{A Dissertation}

Submitted to the Graduate Faculty of the Loufstang State University and Agricultural and Mechanical College in partial fulfullment of the requirements for the degree of Doctor of Philosophy

in

The School of Health, Physical Bducation, Recreation and Dance

by

John Francis Harper

B.A., University of South Carolina, 1973

M.A.T., University of South Carolina, 1975

August 1982 


\section{ACKONOWLEDGMENTS}

The author wishes to thank Dr. Evelyn Hall, Dr. Val Lance, Dr. Amella Lee, Dr. Jack Nelson, Dr. Scotty Powers, Dr. Harold Silverman, and Dr. Mike Stone for their time and effort put into this investigation. The author also wishes to thank Gable Church for her much needed help In the statistical analysis of the data.

A very spectal thanks goes to my major professor, Dr. Ron Byrd, whose leadership, patience, and continual guldance in this endeavor were Invaluable. Acknowledgment would be incomplete without mention of the many people who gave of their time helping me collect the data (Charlie Hardy, Fred Fridinger, Tricta Hopkins, Gay RusBe11, Dennts Tallini, and Ed Walkwitz).

Also, many thanks go to my very apeclal parents whose encouragement and financial help were there whenever I needed them. Most Importantly, praise goes to Almighty God who gave me and those who helped with this research the potential to be creative and the abilities to perform. 
Page

ACKNOWLEDGMENTS $\ldots \ldots \ldots \ldots \ldots \ldots \ldots \ldots \ldots \ldots \ldots$

LIST OF TABLES $\ldots \ldots \ldots \ldots \ldots \ldots \ldots \ldots \ldots \ldots \ldots \ldots \ldots \ldots$ v

LIST OF FIGURES $\ldots \ldots \ldots \ldots \ldots \ldots \ldots \ldots \ldots \ldots \ldots \ldots \ldots \ldots$ vi

ABSTRACT $\ldots \ldots \ldots \ldots \ldots \ldots \ldots \ldots \ldots \ldots \ldots \ldots \ldots \ldots \ldots \ldots \ldots$ v11

CHAPTER 1 - INTRODUCTION ................. 1

Rev lew of Literature ................. 4

Cardlovascular Responses to static Work ... 4

Heart Rate ........................ 5

Blood Pressure .....................

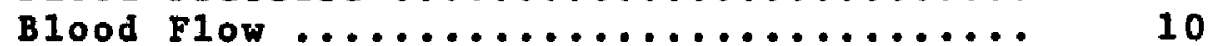

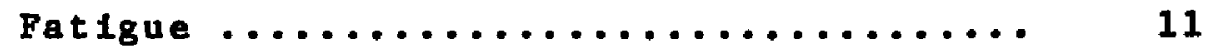

Endurance ...................... 12

Card lovascular Responses to Dynamic Work... 15

Blood Pressure .................... 15

Perlpheral Resistance and Blood

Flow Distribution ................ 16

Heart Rate, Stroke Volume, and

Gardiac output .................. 17

Cardlovascular Responses to Combined

static and Dynamic Work ............... 18

Cardlovascular Adaptations to Aerobic

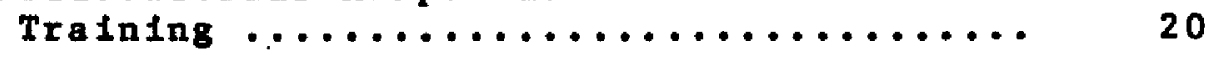

statement of the Problem ............... 24

Research Hypotheses .................... 24

Assumptions $\ldots \ldots \ldots \ldots \ldots \ldots \ldots \ldots \ldots \ldots \ldots \ldots \ldots . \ldots . . \ldots$

Limitations of the study ............... 25

significance of the study .............. 25

CHAPTER 2 - METHODS .................... 28

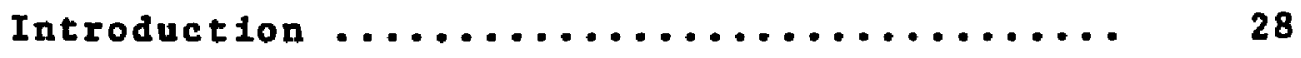

subjects .......................... 28

Testing Procedures ................... 30

Statistical Analysis ................ 33 
CHAPTER 3 - RESULTS AND DISCUSSTON ................. 35

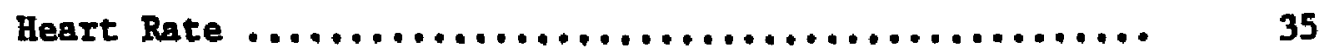

Blood Pressure ............................ 38

Pressure Rate Product ........................ 41

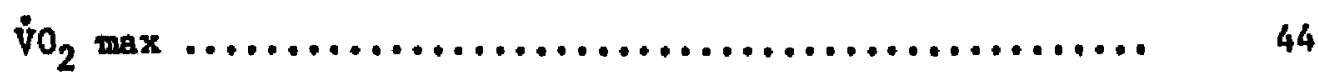

sumary and Conclusions $\ldots \ldots \ldots \ldots \ldots \ldots \ldots \ldots \ldots \ldots . \ldots . \ldots 6$

REFERENCES $\ldots \ldots \ldots \ldots \ldots \ldots \ldots \ldots \ldots \ldots \ldots \ldots \ldots \ldots \ldots \ldots \ldots \ldots \ldots$

APPENDIX A $\ldots \ldots \ldots \ldots \ldots \ldots \ldots \ldots \ldots \ldots \ldots \ldots \ldots \ldots \ldots \ldots \ldots \ldots \ldots$

$\operatorname{vITA} \ldots \ldots \ldots \ldots \ldots \ldots \ldots \ldots \ldots \ldots \ldots \ldots \ldots \ldots \ldots \ldots \ldots \ldots \ldots \ldots \ldots . \ldots \ldots$ 


\section{LIST OF TABLES}

$\begin{array}{ll}\text { TABLE NO. } & \text { PAGE }\end{array}$

1 DESCRIPTIVE DATA OF SUBJECTS ................... 29

2 MEANS AND STANDARD DEVIATIONS FOR $\mathrm{VO}_{2} \max \left(\mathrm{ml} \cdot \mathrm{kg}^{-1} \cdot \mathrm{mln}^{-1}\right) \ldots \ldots \ldots \ldots \ldots \ldots \ldots \ldots, 45$

A1 DEPENDENT VARTABLES BY SUBJECT STATTC AND DYNAMIC WORK ................ 59

A2 DEPENDENT VARIABLES BY SUBJECT COMBINATION WORK $\ldots \ldots \ldots \ldots \ldots \ldots \ldots \ldots \ldots \ldots \ldots . . \ldots$

A3 MEANS AND STANDARD DEVIATIONS BY GROUPS AND TRIALS $\ldots \ldots \ldots \ldots \ldots \ldots \ldots \ldots \ldots \ldots \ldots, 61$

A4 ANALYSIS OF VARIANCE FOR HEART RATE ............. 62

A5 ANALYSIS OF VARIANCE FOR SYSTOLIC BLOOD PRESSURE ....................... 63

A6 ANALYSIS OF VARIANCE FOR DIASTOLIC BLOOD PRESSURE ........................ 64

A7 ANALYSIS OF VARIANCE FOR PRESSURE RATE PRODUCT ........................ 65

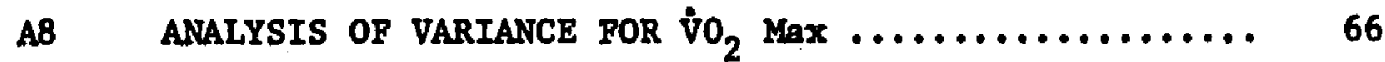

A9 WILKs' LAMBda MaNova $\ldots \ldots \ldots \ldots \ldots \ldots \ldots \ldots \ldots \ldots \ldots \ldots, 67$ 
LIST OF FIGURES

FIGURE NO.
PAGE

1 MEANS AND STANDARD ERRORS FOR HR

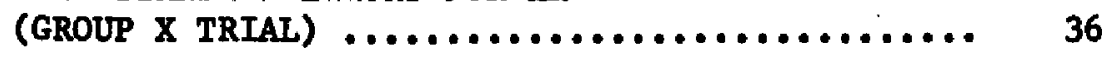

2 MEANS AND STANDARD ERRORS FOR SYSTOLIC AND

DIASTOLIC BLOOD PRESSURE (GROUP X TRIAL) ...... 39

3 MEANS AND STANDARD ERRORS OF MAXIMUM

PRESSURE RATE PRODUCTS (GROUP X TRIAL) ....... 42 


\section{ABSTRACT}

Eighteen male subjects participated in an investigation to examine the effects of static, dynamic, and combination work (static and dynamic) on the variables heart rate, systolic and diastolic blood pressure, pressure rate product, and maximal oxygen consumption $\left(\mathrm{V}_{2} \max \right)$. The subjects, who were all free from any cardiovascular problems, were divided Into 3 groups based on their maximum oxygen consumption levels. The high (Group I), moderate (Group 2), and low (Group 3) aerobic capacity groupg had mean $\dot{\mathrm{V}}_{2} \max 1$ levels of 64,55 , and $47 \mathrm{ml} \cdot \mathrm{kg}^{-1} \cdot \mathrm{min}^{-1}$, respectively. Each subject performed a static test (holding a weighted brief case), a dynamic test (walking on a treadmill) and a comblnation tegt (holding a welghted brief case while walking on a treadmili). Workloads for all subjects were relative to their $\mathrm{vo}_{2}$ max level and to their maximum voluntary contraction. In addition to the static test, dynamic test, and the combination test, which were counter-balanced to prevent any ordering effect, the subjects also performed two maximal treadmill tests in order to observe whether otatic contractions during maximal work would Increase $\mathrm{Vo}_{2} \max$. The first was a standard dynamic treadmill test while the second followed the same protocol with the addition of a static component during the last 2 minutes.

Statistical ansiysis (MANOVA, ANOVA, Duncan's Mult1ple Range Test) revealed that aeroblc fitness level did not affect the heart rate, blood pressure, or pressure-rate product response to the three types of work examined. Furthermore, $\mathrm{vo}_{2}$ max was not Increased by the addition of static work during a maximal test. Heart rate and pressure rate product were significantly higher $(p<.05)$ during combination 
work than during dynamic work, and during dynamic work they were olgnificantly higher than during otatic work. Dlastolic blood presBures were significantly different across all three modes of work. Ordered from high to low, they were static work, combination work, and dynamic work. Systolic glood pressure was significantly higher for combination work, but measures taken during static and dynamic work were not oignificantly different. 
CHAPTER 1

INTRODUCTION

\section{Card Lovascular Responses to Static Work}

Although the cardiovascular changes that occur whlle performing dynamic or static exerclse have been studied extensively, relatively Iittle attention has been concentrated on the hemodynamic effects of combined dynamic and static work. There has been consistency in the literature regarding the cardlovascular responses during atatic and dynamic work. However, there has been disagreement about the cardiovascular changes occurring during combination work (dynamic plus static).

Lindhard (1920) was the f1rst to report on the cardlovascular and resplratory responses to static work. He noted that static contractions occluded the blood flow to the muscles. Since then, many researchers have Investigated the effects of static contractions on blood pressure (BP), heart rate (HR), cardlac output, blood flow, peripheral vascular resistance, and ventilation.

Systolfc and diastolic BP have been noted to increase during handgr1p contract lons (Humphrey \& Lind, 1963; Lind McN1co1, 1965; Lind, Taylor, Humphreys, Rennelly, \& Donald, 1964), and the degree of BP elevation is influenced by the percentage of the maximum voluntary contraction (MVC) and not by the absolute force Involved (Lind \& McNicol, 1967a). In addition, when two different muscle groups contract simultaneously at identical percentages of their MVC, the BP response 18 the same as if only one of the muscle groups was contracting. 
If two different muscles contract at different percentages of their respective MVC, then the pressure response is determined by the mscle contracting at the higher relative percentage of its MVC (LInd \& McN1col, 1967a, 1968).

Heart rate Increases can be seen In less than 1 second after the Initiation of an isometric contraction (Freyschuss, 1970), but quickly reach a steady state level if the contraction 1s oustained below $15 \%$ of MVC (LInd \& McNicol, 1967c). At sustained tensions above 15\% of MVC HR, BP, and cardiac output all continue to rise in an approximately Inear fashton (Humphreys \& Lind, 1963). However, it 1s uncommon to find HR values above 120 beats $\cdot \mathrm{min}^{-1}$ at the point when subjects can no longer maintain a specified percentage of their MVC (LInd, 1970).

\section{Cardiovascular Responses to Dynamic Work}

The cardiovascular responses to dynamic work show many differences from those described for static effort. The key to the differences lies in the fact that generally during dynamic work larger muscle masses are Involved and the blood flow to the muscle is not reduced to the extent that it is during static work. If large muscle masses are involved, as In running, HR Increases to meet the demands for both oxygen and heat transport. Vasodilation in the contracting muscles, followed by cutaneous vasodilation, results in a decrease in total peripheral reslotance (Astrand \& Rodahl, 1977; MacDonald, Sapru, Teylor, \& Donald, 1966). The fall of peripheral vascular restatance allows the active miscle to be perfused with blood with only a small rise in BP during mild rhythmical contractions (Lind \& McNicol, 1967c). 
Card tovarcular Responses to Combined Static and Dynamic Work

Although there 18 some disagreement regarding the cardiovascular effects from combination work, the majorlty of evidence suggests that combined work has a higher physlological cost than the aum of equivalent levels of dynamic and static work done separately (Jackson, Reeves, Sheffield, Burdeshaw, 1973; Lind McNicol, 1965; Sanchez, Monod, \& Chabaud, 1979). ThIs augmentation could place persons who have coronary heart disease in danger.

Ang ina normally follows a rise in the work of the myocardtum to a level which is essentially fixed in each patient. The level at which ang Ina begins is consistently related to the product of HR and systolic BP (Robinson, 1967). Any atatic exertion, which often occurs suddenly In everyday 1ife, can place a person close to dangerous circulatory overload with little warning; "Alrport Angina", which ts a severe and unexpected angfna that some persons experience while walking at a normal rate through an airport while carrying a briefcase or sultcase, represents this situation very clearly (Jackson et al., 1973).

\section{Responses to Aerobic Training}

Training by aeroblc activities ls known to decresse arterlal BP and $H R$ and to increase myocardial effictency, efficlency of peripheral blood distribution and return, and red blood cell mass, all of which can Increase maximal levels of oxygen consumption and therefore Increase aeroblc performance (Clarke, 1972). A question which needs to be . addressed is whether or not aerobic training can reduce the card10vascular stresses imposed upon the body during combination work (static and dynamic combined). One method of answering this is by comparing 
low, moderate, and highly aerobically trained groups under three different conditions: (1) static work; (2) dynamic work; and (3) a combination of static and dynamic work. A highly aerobically trained group would be expected to respond with lower arterlal BP, HR, and pressure-rate product (PRP) than the lower aerobic capactty groups. If such a consequence of this prediction should be substantlated, there would be additional support for aerobic training of both normal persons and those with heart disease.

\section{Revlew of Literature}

Cardlovascular Responses to Static Work

Static (1sometric) contractions do not constitute work according to physical laws, since no external movement occurs. However, the muscle fibers do change in length, which requires the use of energy and can be very fatiguing if the blood flow to the muscle ls not adequate to renew the substrate utilized in the muscle contraction. It is common to describe static work in terms of the product of developed tenston multiplied by the tIme of contraction (Âstrand \& Rodah1, 1977). Although purely static work is an unusual occurrence in daily activities, cardfovascular responses have been extensively documented in the literature.

Lindhard (1920) discovered that during the recovery period followIng a strong contraction in which the oubject had hung by the hands from a beam with flexed-arms (pull-up posftion), a greater increase' in oxygen uptake and cardiac output occurred than that observed during the actual contraction. He concluded from this recovery data that during the period of contraction the muscles were occluded by mechanical 
compression. Since then, many groups of researchers have Investigated th1s phenomenon. Asmussen and Hansen (1938) noted an immediate Incresse In oxygen uptake, stroke volume (SV), HR, and BP when they had subjects push with both lega against a dynamometer. During recovery, oxygen uptake and cardiac output Increased slightly and then dropped toward resting values, while BP and HR dropped immedlately.

\section{Heart Rate}

By far the most extensively reported cardiovascular responses to static work have been on HR and BP. Alam and SmIrk (1938) Inflated a sphygmomanometer cuff placed around one ankle to a pressure of $200 \mathrm{~mm} \mathrm{Hg}$, which arrested the blood flow through the foot. The foot was then exerclsed by alternate dorsi and plantar flexion of the toes. In a series of over 30 experiments it was observed that, when exercise was performed by the calf muscles while the blood flow was occluded, the HR increased and remained elevated an average of 11 beats.min-1 after cessation of exercise if occlusion was maintained. Upon reestablishing circulation the HR Increased silghtiy before returning to normal values in 1 to 2 min. This temporary acceleration of the pulse accompanied by hyperpnea was believed to be caused by the action of the metabolites which were relessed from the legs into the general circulation. Alam and Smirk (1938) also performed a similar experiment wthout occlusion of the blood flow. This experiment indicated that the maintenance of a high pulse rate following exercise ts dependent upon the arrest of the . circulation. When the blood flow to the legs was occluded, but no exerclse was performed, 11ttle change in pulse rate was observed for the $f$ irst $10 \mathrm{~min}$ of occlusion. These results indicated that metabolites 
formed during muscular exercise and retained in the muscles by the arrest of the circulation caused the pulse-accelerating reflex.

Knox (1951) attempted to separate the effects of an exercise containing both static and dynamic components on HR. Subjects initially pulled on springs with both arms and held this stretch for 20 sec. Subsequently, the subjects moved their arms in the same way, but with no tension in the oprings. Heart rate in the dynamic experiment aubtracted from the HRs in the dynamic plus static experiment indicated that the static effort caused a HR increase of about 10 beat $s \cdot \mathrm{m}^{-1}$ after $20 \mathrm{sec}$. Rnox concluded that both static and dynamic exercise affect $\mathrm{HR}$ and that the effects are additive. Tuttle and Horvath (1957) substantlated the effects of static work on HR by having their subjects squeeze a hand dynamometer at maximum effort for one minute. The HR increased from 66 to 93 beats.min-1 within 15 sec and showed only a moderate Increase to 97 beats.min -1 at the end of $45 \mathrm{sec}$ of work.

In an attempt to determine the cause of increased HR during static exerc1se, MacDonald et al. (1966) compared HR responses to sustained handgrip contractions at $30 \%$ uVC under two conditions: (1) normal contraction and (2) contraction after $10 \mathrm{mg}$ of propranolol had been injected Intravenously. The HR response during the handgrip contraction following administration of propranolol was found to be significantly Increased over that during the contraction without propranolol when expressed as a percentage of the resting value. It was felt that a part of the HR response to the contraction was adrenergic in nature, although the rapid incresse in $\mathrm{HR}$ at the infitiation of a contraction suggested that primarily neural rather than humoral mechanisms were Involved. 
Freyschuss (1970) also used $10 \mathrm{mg}$ of propranolol in a simflar experiment but found essentially no difference in the magnitude of the HR Increase when compared to contractions without propranolol present. The deviation between the findings of MacDonald et al. (1966) and Freyschuss (1970) might be explained by the fact that the HR was measured at different time Intervals from the start of the contraction, $7 \mathrm{sec}$ and $60 \mathrm{sec}$, respectively. Freyschuss (1970) and MacDonald et al. (1966) agreed that propranolol did modify, but not abolish, the HR response to static work by blocking the beta-adrenergic receptor 8 , and that at least part of the HR response during exerclae was possibly a result of vagal inhibition. Petro, Hollander, and Bouman (1970) concurred and further suggested that the muscle spindles wight be involved in the reflex decrease of vagal dominance.

Lind and McNicol (1967a, 1968) reported that, when two or more muscle groups contracted at the same relative tension, the HR response was the same whether they contracted together or separately. This finding was substantiated in 1970 by Freyschuss. Furthermore, if two or more muscle groups contract simultaneously at different relative tenstons, the HR response was determined by the muscle group contracting at the higher relative tension.

Additional studies of the HR response to 1sometric contractions have been reported by Bruce, LInd, Franklin, Mulr, MacDonald, McNicol, and Donald (1968) who examined the effects of fatigue on BR during exhaustive exercise. A modest increase in HR of 23 bests.min ${ }^{-1}$ was observed at the Instant the aubject could no longer hold a contraction at $30 \%$ MVC. The HR fell abruptiy after the contraction ended. These 
results were in agreement with earlier work by Lind and McNicol (1967c) and point to the importance of neural controlling factors.

\section{Blood Pressure}

The 1Iterature is replete with the effects of Isometric contractions on BP. As early as 1877, Gaskell described the relationship between muscular activity and blood flow to active muscles. Gaskell described two opposing features: (1) a local vasodilation of the local vessels which he deduced to be caused by a substance released from the muscles, and (2) a throttling effect (mechanical constriction) of the blood vessels by the compression of the contracting muscle fibers. Lindhard (1920) also reported that occlusion of blood flow in the muscles was caused by mechanical compression of the blood vessels during muscular contractions.

However, it was not until 1937 that the mechanlsm responsible for the Increased BP during Isometric contractions was exclusively invest1gated. Alam and Smirk (1937) observed a BP ralsing reflex arising from muscular exercise of a limb when the circulation through its working muscles was arrested by mechantcal pressure. They concluded that the rise in BP was caused by the passage of nerve impulses out from the exercised muscle and that these nerve impulses were caused by the accumulation of metabolites in the muscle. When these metabolites were maintained in the muscle by local arrest of the circulation, the BP reflex was maintained. Blood pressure was found to Increase before many subjects reported experiencing pain, and BP fell at once when circulation through the $1 \mathrm{fmb}$ was re-established, indicating that adrensiline was not the BP raising stimulus (Alam \& Smirk, 1937; Humphrey \& Lind, 1963). 
Thompson (1954) reported that isometric work caused a significant rise in diastolic presgure and suggested that the cause was reflexive In nature. Similar regults were reported by Tuttle and Horvath (1957) who had subjects squeeze a hand dynamometer at maximum effort for $1 \mathrm{~min}$. Systolic and diastolic BP rose from a resting value of $120 / 82$ to $161 / 109 \mathrm{~mm} \mathrm{Hg}$ at the end of work. Research by Whipp and Dav1s (1970) oubstantiated this rise in diastolic pressure.

Lind et al. (1964) measured cardlac output, forearm blood flow, aortic BP, and HR in subjects performing handgrip contractions at 10 , 30, and 50\% MVC while in the supine position. The sustained handgrip contractions caused an abrupt rise in BP which returned to normal within 1 min after contraction had ended. This BP rise was shown to be due to a rise in cardiac output which, in turn, was dependent on an increase in HR. The syatemic vascular resistance showed little or no change, and the SV did not increase at any time during the contractions and in fact decreased in a number of Instances at the higher levels of exertion. Compared to the response to dynamlc exercise, there was a disproportionate rise in cardiac output in relation to the increase of oxygen uptake. The fact that the muscle receiving an Inadequate blood oupply can Invoke powerful central circulatory reflexes designed to Increase 1ts perfusion presgure and circulation, and the fact that this reflex occurs in the presence of complete circulatory occlusion, Indicates an afferent neural pathway.

These results were in agreement with research by Staunton, Taylor and Donald (1964) who postulated that active contraction of muscle cells under naturally or artifically occurring lschemic conditions caused stimulation of local receptors responsible for inftiating and 
maintaining a pressor reflex. This pressor reflex operates such that perfuston pressure progressively Increases as blood flow becomes inadequate for metabolic requirements or for the removal of metabolites. This increase in perfusion pressure is potentlated by external vascular occlusion to the working muscle.

\section{Blood Flow}

Although vasodilation occurs in a muscle during a contraction, blood flow Is often hindered by the mechanical compression of the vessels by the contracting muscles. Barcroft and Millen (1939) reported that blood flow through the calf muscles during sustained contractions was cut off at a tension of $1 \mathrm{ess}$ than $20 \%$ of MVC. Later evidence strongly suggested that the blood flow was not cut off by mechanical compression in the legs at a tension of $20 \%$ MVC, but by "nipping" of the artery between shortening of the soleus and gastrocnemlus muscles (Bumphreys \& Lind, 1963).

Humphreys and LInd (1963) conducted experiments to estimate the tension at which intramuscular pressure overcame the perfusion pressure of blood through the contracting muscle, and to assess the functional significance of the blood flow through the muscle during the contractIons. Using a Whitney (1953) strain-gauge plethysmograph, Humphreys and Ind were able to show that blood flow through the forearm increased during handgrip contractions sustained at tensions up to at least $70 \%$ MVC. At tensions above $70 \%$ MVC intramuscular pressure occluded the blood supply, and the rate of fatigue (the point at which a opec1fled percentage of MVC could no longer be held) was Inversely related to the Increase in muscle tension. 
Humphreys and IInd (1963) determined that the Increased blood flow went only to active muscles by measuring the temperature in both active and inactive muscles during contractlons. Metabolism was eliminated as the main cause of the Increase in muscle temperature by applying arterial occlusion to the contracting arm, resulting in only a small temperature Increase. They concluded that during stat1c work the Increased blood flow goes directly to the active muscle and that there was no increase in blood flow to the inactive muscle, although there was an increase in perfusion pressure. Because there was an Increase in BP with no Increase in blood flow to the Inactive muscles, this Indicated that there was vasoconstriction in the Inactive muscles.

Fatigue

Fatigue, or the Inability to maintain a contraction at. a specified percentage of MVC, was Investigated by Lind and McNicol (1967b) who had gubjects perform sustained handgrip contractions from 5 to $20 \%$ MVC. Tensions maintained above $15 \%$ MVC were found to eventually cause a decrement in performance, while contractions held at tenstons below $15 \%$ MVC did not. Lind et al. (1964) had earlier reported that muscle contractions at a tension of $10 \%$ MV appeared to be indefatigable (one subject maintained this tension for more than 1 hour without fatigue). Th1s led to the conclusion that at tensions below $15 \%$ wN the blood supply to the muscles was adequate for the metabolic needs. Also, in the normal physiological state, the blood perfusion of the muscles during and after contractions is related to the metabolic requirements of the muscle. Any post-exercise hyperemia following sustained contractions bears a close relationship to the metabolism of the active muscle. 
Endurance

Muscle endurance is affected by blood flow (Barcroft Millen, 1939; LInd \& HcNicol, 1967b; Start \& Holmes, 1963), motivation (Johnson Nelson, 1967; Simonson, 1971), and temperature (Clarke, Hellon, Lind, 1958; LInd, 1959). Bruce et al. (1968) conducted a serles of experiments to establish the reproducibility of responses to handgrip contractions over a 10-day perlod. Analysis of the 10-day serles showed that the most reproducible measurement, having a coefficient of varlation of $4.5 \%$, was the MV performed at the start of each experiment. The average duration of any of 3 successive contractions sustained at a tension of $30 \%$ MVC had a coeffictent of variation of about $20 \%$ for the inftial 2 days and fell to $7 \%$ for the last 2 days of testing. Both HR and BP values remained the same at the point of fatigue during all contractions.

Kroll (1968) reported that low-level strength groups fatigued more slowly then high- and middle-level strength groups. A 20-lb difference In maximum strength existed between each of the three groups. These results suggested that the Impediment of blood flow, which is the main contributor to fatigue in static work, might depend upon the absolute rather than the relative musle tension. It appears from similar results reported by Mundale (1970) that relative lsometric grip endurance is inversely related to the absolute loometric grip strength and the contraction time. Mundale concluded that "weaker subjects can maintain a higher proportion of their maximal strength during proilonged activity than those with superior strength."

Recovery of the ability to exert maximum tension after fatigue in Isometric contractions performed at one-third of MVC was $90 \%$ complete 
In $7 \mathrm{~min}$ and $100 \%$ complete after $20 \mathrm{~min}$ (Lind, 1959). However, recovery to maintain maximum duration for a sustained contraction at one-third maximum tension was only 70 to $75 \%$ complete after $40 \mathrm{~min}$, and full recovery took several hours (LInd \& McNicol, 1967a).

Stephens and Taylor (1972) reported that fatigue of maintained MVC occurs in two phases. In the first, lasting for around $1 \mathrm{~min}$, force falls to about $50 \% \mathrm{MVC}$, and in the second phase force falls at a relatively slower rate than in phase one. They interpreted their results as ind icating that fatigue arises Inttially from neuromucular Junction fatigue, but later contractile element fatigue becomes progressively more important. Because the blood supply is cut off during the first stage, artertal occlusion would make no difference in the progress of fatigue. However, during the second stage as force falls, blood flow returns to the muscle; and fatigue progresses little further unless occlusion 1s maintained by external mechanlcal compression.

Recovery from static work 18 much faster than from dynamic work. Little, If any, oxygen debt is incurred (LInd et al., 1964; Tuttle \& Horvath, 1957); and BP and AR usually have returned to resting levels within 1 minute after cessation of exercise. Simonson (1971) discusses many other causes of fatigue during static work in addition to those mentioned above.

Papers published in 1967 (Donald, Lind, McNicol, Humphreys, Taylor Staunton; Lind \& McNicol c) and in 1968 (Lind \& McNicol) present excellent reviews of the cardlovascular responses to static contractfons. The degree of BP elevation was reported to be Influenced by (1) the percentage of the MV of the muscle Isometrically contracting and not of the absolute mass Involved; (2) If two different muscle 
groups contracted simultaneously at Identical percentages of their MVC, the BP response was the same as if only one of the muscle groups was contracting; and (3) If two different muscles contract at different percentages of their respective MVC, then the pressure response is determined by the mucle contracting at the higher relative percentage of It $\mathrm{s}$ MVC.

Percentage of MVC as a determinant has recently been questioned by Buck, Amundsen, and Nielsen (1980); Freund, Hobbs, and Rowell (1978); and Saltin, Mitchell, Schibye and Payne (1978). Buck et al. (1980) evaluated systolic BP responses during 1sometrlc contractions of large and small muscle groups and reported that systolic BP fncreased more rapidly and reached higher absolute levels during fatiguing handgrip contractions at $40 \%$ MVC compared to similar contractions of index finger adductor muscles. Lind and McNicol (1967a) had suggested that a lower limit of muscle mass may exist which is required to elicit a maximal pressor response to a sustained muscle contraction. This could explain the differences between the results of the two studies. McCloskey and Streatfeild (1975) substantlated the Importance of percentage MVC by examining the pressor responses to handgrip and finger exercise. However, Buck et al. (1980) disagreed with McCloskey and Streatfelld's findings, maintaining that there was no significant difference between the muscle mass of the index $f$ inger adductor muscle and the flexors of the 1ittle finger. Buck et al. (1980) also belleved that additional muscle recruitment had occurred in the studies by Lind and McNicol (1967a) and by McCloskey and streatfelld (1975) which may have affected their results. ThIs was based upon the fact that, during a sustalned Isometric handgrip contraction, a progressive 
spread of excitation to synergistic muscles occurs as fatigue ensues (Ramos, Mundale, Awad, Witsoe, Cole, 01son \& Kottke, 1973). The amount of recruitment and the rise in BP were related to the degree of intenBity and duration of the contraction.

\section{Card Lovascular Responses to Dynamic Work}

Dynamic work is certainly the most common type of work. Whenever an external mass is moved some distance, dynamic work can be quantified as a product of the developed force multiplied by the vertical displace-

ment (Åstrand \& Rodah1, 1977). Dynamic work can be observed often in day-to-day activities such as walking and running. Adjustments made by the cardfovascular systen to dynamic work have been extensively reported, so will not be documented in detall here. A cursory review of the effects of dynamic work on BP, peripheral resistance, blood flow distribution, HR, and SV will be given.

Blood Pressure

Blood pressure during dynamic work has been reported to respond very differently from that during static work (Bruce et al., 1968; IInd, et a1., 1964; LInd McN1col, 1967c; Tuttle \& Horvath, 1957). Normally, the systolic pressure is Increased during exertion, and the amount of Increase is dependent upon the severity of exertion. The diastolic pressure remains unchanged or might decrease or Increase only slightly, while the mean pressure increases in proportion to the Increases in systollc and diastolic pressures.

Arterfal BP 18 Influenced by (1) cardiac output, (2) peripheral resistance, (3) elasticity of the arteries, (4) viscosity of the blood, and (5) blood volume (Ástrand \& Rodahl, 1977). During dynamic exercise, 
cardiac output and peripheral resistance are the main determinants of the BP response. With increasing levels of dynamic work, the cardiac output is increased in response to an increase in $\mathrm{HR}$.

It is important to use a standard procedure in the measurement of BP, because the method by which BP is determined and the location of measurement are important considerations in obtaining reliable and valid measurements. Systolic pressure normally increases, and diastolic pressure decreases as the point of measurement moves from the aorta to more peripheral arter 1es at rest (McDonald, 1960) and during upright exercise (Rowell, Brenglemann, Blackmon, Bruce \& Murray, 1968). Kuhlemeler (1972) reported a correlation of $r=.96$ between Invasively measured aortic and auscultatory measured brachial mean blood pressures, Indicating that an exercise test which estimates central persoures from peripheral pressures is feasible.

Peripheral Resistance and Blood Flow Distribution

The normal response to dynamic exercise is a dilation of blood vessels in the active muscles (and later in the skin to reduce body heat) and a constriction of vessels in the splanchnic, renal, and hepatic beds. As a result of these changes, systemic vascular resistance may fall as much as $50 \%$ of the level found at rest (LInd \& McNicol, 1967a). Th1s fall in resistance obscures the significant visceral vasoconstriction, thereby maintaining mean arterlal pressure (Rowell et al., 1968).

Blood flow is Incressed to the active muscles as dilation of their vessels occurs in proportion to the metabolic demand and 18 shunted away from the visceral area where it 16 not vitally needed. In general, 
blood flow to the non-working muscles and internal organs (except the heart) decreases, and that to the working muscles Incresses in proportion to the workload, while cerebral blood flow remains constant throughout exerclse.

Heart Rate, Stroke Volume, and Cardlac Output

It is well established that HR Increases IInearly with increasing workload (Astrand Rodahl, 1977). Normally, the HR Increase is relatively large at the start of exercise and then nears steady state within 30 to 60 sec if the work is 1 ight or moderate (deVries, 1980). However, at higher workloads a steady state may not be achleved; and HR may reach maximal levels shortly before exhaustion occurs. Normal 1imits have been determined for maximal HR levels for each year of age, and there is a gradual decline In maximal HR with increasing age (Ellestad, Allen, Wan, Kemp, 1969). Maximal HRs are around 200 beats.min ${ }^{-1}$ in healthy young men, but a standard deviation of \pm 10 beats.min-1 exists for maximal HR during exercise.

Stroke volume also increases during upright dynamic exercise and reaches a maximal value at a workload with an oxygen uptake of about $40 \%$ of the maximum and a HR of about 110 - 120 beats.min-1 (Astrand, Cuddy, Saltin, \& Stenberg, 1964). Further, In healthy young subjects SV did not decrease during maximal exerclse at HRs of or above 200 beats.min ${ }^{-1}$, Indicating that diastolic filling of the heart was not reduced at these rates.

The increase in HR and SV can elevate cardiac output to six times the restıng level (Ástrand et al., 1964; Astrand \& Rodahl, 1977). At exerclae levels up to 40 to $60 \%$ of a person's maximum capacity, Increases 
In both HR and SV are responstble for the Incresse in cardlac output. When exercise levels are higher, the increase results entirely from the continued increase in HR.

Cardiovascular Responges to Combined Stat 1c and Dynamic Work

Rarely are everyday activities purely static or dynamic in nature, but rather a combination of the two. Unfortunately, the research in this area of combination work has recelved relatively little attention. In 1956, Hellebrandt, Houtz, Hocloman, and Partridge had gubjects perform static contractions with one hand while simultaneously contracting rhythmically with the other. Dynamic exerclse was found to always augment the duration of the atatic contraction. Dynamic work was also Increased, but to a lesser degree. Also, when rhythmic contractions were continued until near fatigue, and then the contralateral hand began doing static work, a reversal in the fat igue curve was observed to occur.

Lind and McNicol (1967a) evaluated the cardiovascular responses to sustained handgrips at three tensions (20, 30, and 50\% MVC) while subjects walked on a treadalil at three different levels of $\mathrm{O}_{2}$ uptake $\left(1.1,1.7\right.$, and $\left.2.81 \cdot \mathrm{min}^{-1}\right)$. The Increments in $\mathrm{KR}$ and BP at 20 and $30 \%$ MVC were simflar at all levels of $\mathrm{O}_{2}$ uptake. However, under the most extreme combination of static and dynamic exercise that Lind and McNicol examined (50\% MVC during treadmill walking at an $0_{2}$ cost of $\left.2.81 \cdot \min ^{-1}\right)$, the BP and HR response was 1 ess than during the milder walking rates. They concluded that the systemic resistance at the fastest rate of walking was 80 reduced by the demands of the dynamic exerclse that the combined effect of Increasing cardtac output plus the 
additional vasoconstriction were not sufficient to produce the normal pressor reaponse to $50 \%$ MVC.

Despite this, the ralsed perfusion pressure due to the static contraction caused an increase in the volume of blood flowing through these muscles engaged in isometric contraction and presumably also through these muscles performing rhythmic exercise. Finally, the mechanical resistance to flow caused by the isometrically contracting muscles coutd Increase the volume of blood available to the general circulation for rhythmic contractions (Lind IcNicol, 1967a). Although the hemodynamics are quite different In rhythmic and lsometric work, the cardiovascular responses to sustained handgrip contractions while walking on the tradmill were typical in both pattexn and magnitude to those obtained when the handgrip was done singly. This is in contrast with Sanchez et al. (1979) and Jackson et a1. (1973) who reported that combined work had a higher physiological.cost (HR and $\mathrm{O}_{2}$ uptake) than the simple sum of the dynamic plus the static work.

Lind and McNicol (1968) and Petrof sky and Lind (1978) evaluated the cardlovascular responses to carrying and 1fting tasks. In an experiment in which teams of two men walked at $2 \mathrm{mph}$ on the level carrying a stretcher, on one occasion by hand and on the other occaston by a shoulder harness, extreme differences in HR and BP were noted. When the stretcher was carried by hand, the BR and mean BP rose steadily with final values at $3 \mathrm{~min}$ being 145 beats.min-1 and $143 \mathrm{~mm} \mathrm{Hg}$, respectively. In contrast, the corresponding values at $3 \mathrm{~min}$ when the . stretcher was supported In a shoulder harness were 124 beats.min-1 and $96 \mathrm{~mm} \mathrm{Hg}$, respectively. The aubjects were fatigued after $3 \mathrm{~min}$ of hand carriage, whereas after $15 \mathrm{~min}$ of carrlage by the shoulder straps, they were not. 
These results not only confirmed earlier research by Lind and McNicol (1967a, 1968) which indicated that it is the proportion of the maximum tension that a muscle exerts rather than the size of the muscle mass which Induces these cardlovascular responses, but it also illustrated the magnitude of cardfovascular stress which can be Imposed on a person by combination work if not done as efficiently as posstble. The fact that combined static and rhythmic effort increases HR disproportionately in comparison with the increase in maximum oxygen consumption $\left(\dot{\mathrm{V}}_{2} \mathrm{max}\right.$ ) has been confirmed often (Lind \& McNicol, 1967a). Minute ventilation has also been shown to increase directly with rhythmic exercise, but disproportionately to the metabolic need when static effort was added, producing an Inefficlent, energy-consuming hyperventilation (Wiley \& Lind, 1975).

\section{Cardiovascular Adaptations to Aerobic Training}

The cardlovascular system has been the center of investigation for many years, but only in the last two decades has the functioning of the cardlovasculat gystem during exercise been intensively examined. Numerous researchers (Clausen, 1976; Ekblom, 1969; Frick, Konttinen, \& Sarajas, 1963; Salt1n, Blomqqust \& Mitchell, 1968; S1egel, Blomqvist, \& Mitche11, 1970) have conducted longltudinal and cross-sectional studies to evaluate heart rate (HR), blood preseure (BP), stroke volume (SV), cardiac output (Q́), pressure rate product (PRP) and maximal oxygen consumption ( $\left(\mathrm{V}_{2} \max \right)$ before and after an aeroblc training program. , Cardiovascular adaptations to aeroblc training are dependent on numerous factors such as the level of fitness at the onset of training, genetic endowments, age, health status, previous training (especially 
regarding length of time and age it occurred), and the actual structure and length of the training program (Froelicher, 1973). Specific considerations must also be given to the type, frequency, duration, and Intensity of the aerobic exercise if optimum cardiovascular gains are to be seen (Froelicher, 1973; Stegel et al., 1970).

It is well known that a reduction in resting HR occurs falrly predictably in response to a perlod of aerobic training and that trained athletes have lower ARs at rest when compared to normal sedentary people (Clausen, 1976; Saltin et al., 1968). The mechanism responsible for this sinus bradycardia at rest is attributed to a greater dominance of the parasympathetic system (Increase in vagal atfmulation) and a reduction in the sympathetic drive. Although other factors such as cardlac hypertrophy, increased blood volume and reduced stimulation from peripheral receptor may also carry some of the responsibility for the sinus bradycardia, they have not been substantlated by conclustve evidence (Clausen, 1976).

In addition to a lower HR at rest, aerobically trained persons, when compared to untrained persons, also have a decrease In HR during submaximal exercise (Boyer, 1972; Buskirk, 1973; Clausen, 1976; Frick, 1968; Froelicher, 1973; Wtlmore \& Norton, 1975). This reduction in HR is belleved to be the result of a larger SV. which 18 attributed to myocardial hypertrophy or to an Increase in blood volume. Froelicher (1973) revlewed 10 training etudies (6 dealing with normal men and the remaining 4 with men having cardiovascular problems). The HR was reduced In all of the trainees, both at rest and during submaximal exerclse, and in the studies in which SV was measured it was increased In every case during maximal and submaximal exercise. 
Cardiac output (HR $x$ SV) has been studied extensively in subjects at rest and while performing submaximal and maximal exercise. In the majorlty of training studies revlewed by Froelicher (1973), cardiac output was reduced at rest following physical training, unchanged at submaximal work, and Increased during maximal exerctse. Frick et al. (1963) reported a $10 \%$ increase in the resting cardiac output following a 2-month training period. This increases was attributed to a larger stroke volume even though the resting heart rates had been reduced. Although there is st111 some controversy in the 11terature regarding cardlac output changes following training programs, the mafortty of 11terature is in support of higher cardiac values for trained persons performing maximal work (Wilmore * Norton, 1975).

The effects of training on systolic and dlastolic blood pressure have been well documented In the 1iterature. Boyer and Kasch (1970) evaluated the effects on BP of a 6-month walk/Jog training program meeting twice week1y in 2 groups of hypertensive and nonhypertensive (norma1) men. Reductions in systolic and diastolic pressures of 13 mn $\mathrm{Hg}$ and $12 \mathrm{~mm} \mathrm{Bg}$, respectively, were noted in the hypertensive group, while the diastolic pressure in the normal group dropped 6 an $\mathrm{Hg}$ with no change in the systolic. The authors commented that the drop in blood pressure was probably due to the vasodilating effect of endurance exerclse.

Montoye, Metzner, Keller, Johnson, Epstein (1972) also reported that more active men had significantly lower systolic and diastolic'BP as evidenced from the Tecumseh Project in which 1700 men were studied. Frick et al. (1963) also reported decreases in their subjects' resting 
systolic, diastolic, and mean pressures following a 2 month training program. Similar findings were presented by Buskirk (1973).

These decreases in BP appear to result from the decreased HR response and to a peripheral vasodilation and blood redistribution during submaximal exercise. Although the greatest changes in BP occur In those persons who at the onset of an exerclse program have an abnormally elevated pressure, the evidence does not discount the benefits of reduced pressures for normals fnvolved in aerobic training.

The trained heart works at a lower rate and ejects a larger volume than the untrained heart. This Increase in stroke volume requires for a given workload a emaller amount of oxygen than an untrained heart. Therefore, the trained heart is more efficlent and can perform with less stress at relative workloads compared to the untrained heart. Myocardial work, myocardial oxygen demand, can be assessed by the pressure-rate product (PRP) (systollc blood pressure $x$ heart rate/100). As work Increases, HR and systollc BP normally Increase, and therefore the myocardial oxygen denand increases. Tratned persons have a reduced PRP at a fixed workload when compared to the untrained (Buskirk, 1973), and therefore they have an improved power function and efficiency of the myocardium (Boyer, 1972; Frick, 1968; Frick et al., 1963).

In addition to these cardfovascular adaptations to aerobic training, the 11terature is replete with studies reporting increases in $\dot{\mathrm{V}}_{2} \max$ following training (Clausen, 1976). Oxygen consumption can be calculated as the product of cardiac output (Q) and the axteriovenous oxygen differ-

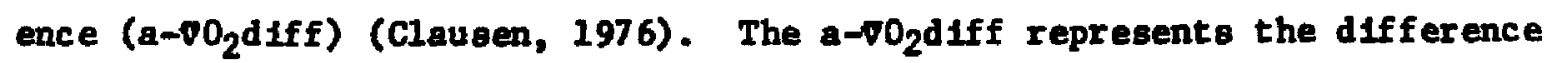
in concentration of oxygen in the arterial and venous blood. An increase In the a-vO $\mathrm{O}_{2} \mathrm{diff}$ Indicates an Increase in oxygen utilization by the 
t1ssues. As the $\dot{Q}$ Increases in proportion to the workload, the supply of blood to the active tissues is Increased. Trained persons have been shown to have an Increased $a-\bar{v} O_{2} d$ iff and $a$ higher $\dot{Q}$ at maximal work levelg (Buskirk, 1973; Wilmore \& Norton, 1975). This greater oxygen extraction from the increased $\dot{q}$ is responsible for the enhanced aerobic capacity in the trained Individual.

In conclusion, the results of a physical conditioning program of sufficlent duration, Intensity, and frequency will induce the physiological changes discussed. These changes enable a person to more efficlently respond to demanding work, therefore placing less atress on the cardlovascular system.

\section{Statement of the Problem}

The purpose of this study was to Investigate the effect of aerobic capacity on cardiovascular responses (HR, BP, PRP) elicited by static, rhythic, and a combination of static and rhythmic work (combination work). Additional experiments were carrfed out to evaluate the effect of an isometric handgrip contraction performed during maximal dynamic work on $\mathrm{V}_{2}$ max.

\section{Research Hypotheses}

It was hypothesized that subjects having a $h$ Igh $_{\mathrm{g}} \mathrm{j}_{2} \max$ would exhlbit a lower BP, $\mathrm{HR}$, and PRP response when compared to subjects with a moderate or $\mathrm{Low}_{\mathrm{V}} \mathrm{\textrm {O }}_{2} \max$ during static, rhythmic, and combination work. It was also hypothesized that an increase in $\dot{\mathrm{V}}_{2} \max$ would occur when an Isometric handgrip contraction was superimposed on maximal dynamic work. 


\section{Assumptions}

1. Al1 subjects exerted maximum effort for determination of their MVC.

2. Paychological or emotional influences on cardlovascular responses were randomly distributed.

\section{Limitations of the Study}

1. Subjects were Instructed not to eat or drink anything other than water for at least 2 hours before each test. Strenuous physical activity was also a suggested constraint for at least 6 hours before a test. There was no assurance that subjects adhered to these recommendations.

2. Psychological factors other than those perceived from exertion may have Influenced each subject's cardlovascular responses.

3. Generalization of the results to persons with cardiovascular heart disease was not possible since subjects in this study were assumed to be free from cardiovascular heart disease.

\section{Significance of the Study}

Card lovascular responses during 1sometric (static) and 1sotonic (rhythmic) work are of interest to researchers, medical practitioners, coaches, and physical educators. Of particulär concern are the effects of 18ometric exercise on BP, HR, cardiac output, left ventricular performance, and myocardial oxygen consumption (Halasly, Messin, Degre, Vandermoten, Demaret, \& Denolin, 1974; Helfant, DeV111a, \& Melster, '1971; KIvowitz, Parmley, Donoso, Marcus, Ganz, \& Swan, 1971; Quarry \& Spodick, 1974; Strong, Miller, Striplin, \& Salehbha1, 1978). 
The pressure rate product has been established as a correlate of myocardial oxygen consumption (Robinson, 1967), and angina pectoris is known to reoccur in patients at a predictable PRP level during graded exercise testing (Wahren Bygdeman, 1971). Due to the augmentation of cardlovascular responses by static work when done concomitantly with rhythic work, persons often unknowingly place themselves in dengerous situations. Th1s is especially true of persons who have coronary heart disease. Angina is normally a result of a rise in the work of the myocardium to a level which 18 essentlaliy fixed in each patient. Wahren and Bygdeman (1971) reported that in coronary heart disease patients HR, PRP, peak systolic, systolic mean, diastolic, and mean arterial pressures all increased more steeply during arm exerclse than during leg exercise even though a smaller workload was performed by the arms. These Increases were assoclated with the use of a smaller muscle mass and with the static component of work performed by the muscles of the back and hip that help to stabilize the body. Static exertion, which often occurs suddenly in everday 1ife, can place a person close to dangerous circulatory overload with IIttle warning. A good example is "atrport angina" which is a severe and unexpected ang tna which some persons exerplence while walking at a normal rate through an alrport while carrying a brlefcase or bultcase (Jackson et a1., 1973).

Aerobic-type activities are known to improve the functional capabilities of the cardiovascular system. A person with a high aeroblc capacity, compared to a person with a low capacity, works at a lower relat ive workload in everyday dynamic activities. An important question 1s whether or not aerobic training can reduce the cardlovascular 
responses Imposed upon the body during combination work. An aerobically trained person would be expected to respond to any standard exercise with lower arter lal BP, HR, and PRP than a person with a low aerobic capacity.

One of the 1imiting factors in aerobic activities is the ability to deliver oxygen to the working muscles. Because isometric work cause a dramatic rise in BP and therefore Increases perfusion pressure and blood flow to the exerclsing muscles, an loometric hand contraction might possibly enhance $\dot{\mathrm{V}}_{2} \max$ and thus benefit athletic performance. The consequences of this study might be (1) additional support for aerobic training of both normal persons and those with heart disease In order to reduce the cardlovascular responses to combination work and (2) support for the use of Isometric contractions during dynamic work In an effort to Increase $\mathrm{V}_{2}$ max and thereby Increase performance. 
CHAPTER 2

METHODS

Introduction

Different cardiovascular responses are ellctted by static and dynamic work. However, the cardlovascular responses from combination work are not easily separated. In order to evaluate the effects of aerobic fitness on cardiovascular responses to comblnation work, three groups having high, moderate, and low levels of aeroblc capaclty were compared under three conditions in a counter-balanced design: (1) static work; (2) dynamic work; and (3) combination work. An additional experiment was used to examine the effect on $\dot{v}_{2}$ max of adding a static contraction during maximal rhythmic work.

\section{SubjectB}

Subjects for this atudy were 18 young, healthy males who were selected on the basis of $\dot{\mathrm{V}}_{2} \max$ (Table 1 ). The design of the study dictated that a prime criterion for acceptance as a subject was that $\dot{\mathrm{v}}_{2} \max \left(\mathrm{ml} \cdot \mathrm{kg}^{-1} \cdot \mathrm{min}^{-1}\right)$ should be below 51 for a low fit group, between 51 and 60 for a moderately fit group, and above 60 for a high fitness group.

Prior to the selection of the subjects, those having any medical or physical 1imitations which would prevent them from engaging in exhaustive exercise were excluded. The exclustion was based on results obtalned from a questionnaire which the potential subjects completed at an orfentation session. As far as could be determined, all subjects were non-smokers and had no physical or mental Impairment which would 
Table 1

Descriptive Data of Subjects

\begin{tabular}{|c|c|c|c|c|c|}
\hline Group & $\begin{array}{c}\text { Age } \\
\text { (yrs) }\end{array}$ & $\begin{array}{l}\text { Height } \\
\text { (cm) }\end{array}$ & $\begin{array}{c}\text { Weight } \\
\text { (kg) }\end{array}$ & $\begin{array}{c}\dot{\mathrm{V}}_{2} \max \\
\left(\mathrm{ml} \cdot \mathrm{kg}^{-1} \cdot \min -1\right)\end{array}$ & $\begin{array}{l}\text { MVC } \\
\text { (kg) }\end{array}$ \\
\hline $\begin{array}{l}\text { Low FIt } \\
(n=5)\end{array}$ & $\begin{array}{l}24 \\
\pm 5\end{array}$ & $\begin{array}{l}179 \\
\pm 3\end{array}$ & $\begin{array}{r}86 \\
\pm 18\end{array}$ & $\begin{array}{l}47 \\
\pm 5\end{array}$ & $\begin{array}{l}58 \\
\pm 7\end{array}$ \\
\hline $\begin{array}{l}\text { Mod Fit } \\
(n=5)\end{array}$ & $\begin{array}{l}22 \\
\pm 2\end{array}$ & $\begin{array}{l}179 \\
\pm 5\end{array}$ & $\begin{array}{l}74 \\
\pm 7\end{array}$ & $\begin{array}{l}55 \\
\pm 1\end{array}$ & $\begin{array}{r}57 \\
\pm 10\end{array}$ \\
\hline $\begin{array}{l}\text { High Fit } \\
(n=8)\end{array}$ & $\begin{array}{l}23 \\
\pm 5\end{array}$ & $\begin{array}{l}178 \\
\pm 8\end{array}$ & $\begin{array}{r}70 \\
\pm 12\end{array}$ & $\begin{array}{l}64 \\
\pm 3\end{array}$ & $\begin{array}{r}56 \\
\pm 11\end{array}$ \\
\hline
\end{tabular}


have affected performance. The ortentation gession allowed the subjects to become famillar with all of the equipment and with the testing procedures. A written summary of the purpose of the study and the procedures to be used in the research were given to each subject, and all gave written consent prior to being tested.

\section{Testing Procedures}

\section{Prel Iminary Tests}

Prior to performing the three tests, the subjects came to the laboratory for an orfentation session during which time they underwent a simulation of all testing procedures. Helght and welght were meagured by standard procedures with the subjects wearing only shorts. Right handgrip MVC was determined at this time by having the oubjects perform three maximal voluntary contractions with durations of less than 2 sec and at intervals of $1 \mathrm{~min}$. The mean of these was accepted as the uVC. A Lafayette $\mathrm{grip}$ dynamometer (Model 78010) was used In this procedure.

During the latter portion of the orientation, Hewlett-Packard electrodes (No. 14389A) were applied to CM5 lead sites following standard skin preparation procedures, and the aubjects underwent the standard or superstandard treadmill test protocol of the International Committee for the Standardization of Physical Fitness Testo (ICSPFT) (Larson, 1974, pp. 476-478). The ICSPFT standard protocol was used on those volunteers who subjectively rated themselves as being only moderately aerobically conditioned. The atandard protocol involved, walking at $3.0 \mathrm{mph}$ at $2.5 \%$ grade for 2 min and Increasing the grade every 2 min until the subjects reached $85 \%$ of their age-estimated maximum HR (220-age). Those subjects who rated themselves as highly 
aerobically conditfoned were tested using the super-standard protocol. Thls Involved walking at $3.75 \mathrm{mph}$ at 47 grade and increasing the grade $2 \%$ each min unt 11 the subjects reached $85 \%$ of their age-estimated maximal $\mathrm{HR}$. The $\mathrm{V}_{2}$ max for all oubjects was estimated by extrapolating the subject's HR to the predicted maximal level and estimating the maximum workload in metabolic equivalents (METS) which could be obtained at this maximum HR. For these and all other tests, HR was calculated from R-R Intervals across four ECG complexes, recorded on a HewlettPackard 1511-B electrocardlograph.

\section{Maximal Treadmill Teat}

To determine actual $\dot{\mathrm{v}}_{2} \max$, the subjects performed the following test based upon their estimated $\mathrm{v}_{2} \max$ from the ICSPFT treadmill test. The oubject warmed-up for $5 \mathrm{~min}$ by walking at a speed and grade calculated to require $30 \%$ of $\dot{\mathrm{V}}_{2} \max$ followed by a speed and grade for $2 \mathrm{~min}$ est Imated to require $80 \%$ of $\mathrm{V}_{2}$ max. Thereafter, continued 27 increases in grade were made each minute until exhaustion was reached.

Measurements of $\mathrm{V}_{2}$ and $\mathrm{HR}$ were made every $15 \mathrm{sec}$ following the warm-up and continued until the test was terminated. Blood pressure was measured by standard auscultatory techniques during the last 30 sec of each min following the warm-up until the test was terminated. The same techniclan made all BP measurements. A standard open c1rcult method was used to meaure $\dot{\mathrm{v}}_{2}$ and the criterion for achievement of maximum was observation of a plateau in $\dot{\mathrm{V}}_{2}$ accompanying an Increase in workload.

Subsequent to the maximal test, a rotation-group technique was ut111zed in the assigment of test conditions to counterbalance any ordering 
effect. A minimum of 2 days elapsed between each of the following: orfentation session, $\dot{\mathrm{V}}_{2} \max$ test, and experimental test conditions. All experimental test conditions were performed on the same day with a 15 min recovery period between each condition.

Static Test

Each subject stood on the treadmill belt with his right hand restIng on the right side railing. The hand rested so that the railing passed between the first and second metacarpals. The oubject then grasped the handle of a briefcase containing weight equivalent to $20 \%$ of the aubject's MVC which was determined on the orientation day. The weight of the handle rested uldway between the head and base of the proximal phalanges 2,3 , and 4 . The subject held the contraction for $5 \mathrm{~min}$, with BP being measured in the left arm during the last $30 \mathrm{sec}$ of each min by the atandard auscultatory method. The same technictan made all BP measurements on all of the subjects. Heart rate was calculated from. ECG recordings which were taken every $15 \mathrm{sec}$.

\section{Dynamic Test}

Subjects walked for $5 \mathrm{~min}$ on the treadmill at a speed and grade estimated to elicit $30 \%$ of their measured $\dot{\mathrm{v}}_{2} \max$. ECG traces were recorded each $15 \mathrm{sec}$ and BP was meaured in the left arm during the last $30 \mathrm{sec}$ of each min by standard auscultatory methods.

\section{Combination Test}

Subjects walked for 5 min on the treadmill at a speed and grade estimated to elicit $30 \mathrm{z}$ of their measured $\mathrm{V}_{2} \max$ while simultaneously 
replicating procedures used in the static test. Heart rate and BP were recorded as in the static and dynamic tests.

Maximal Test Plus Isometric Contraction

Immediately following the last of the three treatments, the treadmill speed and grade were set to a level which demanded $80 \%$ of the subject's $\mathrm{VO}_{2}$ max. Pollowing $2 \mathrm{~min}$ at thls speed and grade, the subject was Instructed to maximally contract and sustain his grip on a rubber ball. Simultaneously, the treadmill grade was increased as in the previous maximal treadmill test until the subject could no longer contInue. The $\dot{\mathrm{V}}_{2}$ max obtained from this test was compared to that from the previous maximal treadmili test to evaluate the effect of the 1sometric contraction. The method of measuring $\dot{\mathrm{V}}_{2} \mathrm{max}$, the times during which data were taken, and the criterion for achlevement of $\mathrm{V}_{2}$ max were exactly as in the previous maximal test.

\section{Statistical Analyols}

A 3(group) X 3(trial) MANOVA with repeated measures on trials was used to determine whether differences existed among three conditions (atatic, dynamic, combination work) and at three levelo (high, moderate, and low aeroblc capactity). The three dependent varlables used in the MANOVA were BR, gystolic and diastolic BP. Following MANOVA, examination of unfvarlates were conducted. Duncan's Multiple Range test were performed on all significant univartates.

Because PRP is a product of SBP and HR a separate 3 (group) X 3(trial) ANOVA was performed to avold multiculinearity. When aignificant differences $(p<.05)$ were found, Duncan's Multiple Range test was performed to 1solate the differences. 
A 3(level) X 2(condition) factorlal analysis of variance was used to determine whether differences exlsted among three fitness levels (high, moderate, and low aeroblc capacity) under two conditions (dynamlc and combination work). Maximum oxygen uptake $\left(m \mathrm{~m} \cdot \mathrm{kg}^{-1} \cdot \min ^{-1}\right.$ ) was the dependent varlable examined in this analyois. 
RESULTS AND DISCUSSION

Regults from the W11kg' Lamda MANOVA Indicated no slgnificant group differences $\left(F_{2,15}-1,45\right)$ but signiflcant trial differences $\left(F_{2,30}=34.04\right)$. Follow up ANOVA's were conducted on the dependent varfables HR, systolic and diastollc BP for the trial differences, and when significant results were found Duncan's Multiple Range tests were performed to isolate the differences between means (Tables A3 - A8). Heart Rate

Significant differences $(\mathrm{p}<.01)$ were found in $\mathrm{HR}$ across trials for all groups (FIgure 1). Significant differences $(\underline{p}<.05)$ in $\mathrm{HR}$ were found between all modes of exercise. Static work was the least demanding, dynamic was intermediate in stress, and combination work was the most Iigorous.

The significant differences that were found across trials were not unexpected, being in general agreement with the 1iterature (Astrand \& Rodah1, 1977; Donald et a1., 1967; Freyschuss, 1970; K1lbom \& Persson, 1981; Lind McNicol, 1967a). The acceleration of HR at the onset of static exercise is a result of vagal withdrawal and to a function of the percentage of MVC Involved (Shepherd, Blomqviot, LInd, Mitchell, \& Saltin, 1981). Besides vagal withdrawal, this contraction also caused Increased sympathetic activity, the combination increasing $\mathrm{HR}$ to the , appropriate level within seconds. Increased $\mathrm{HR}$ and the squeezing-out of venous blood from the muscles at the beginning of the static exercise 


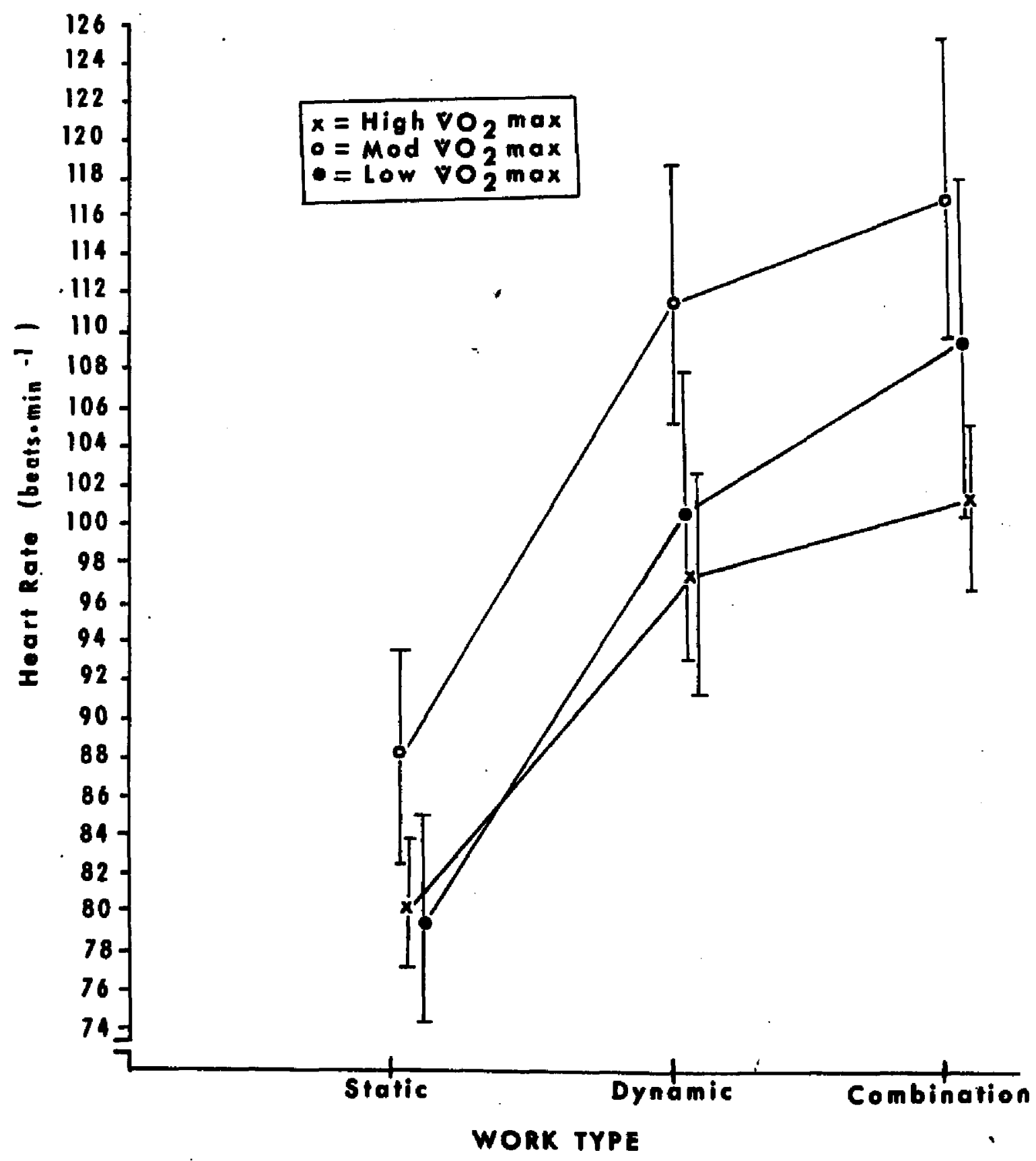

Figure 1. Moans and standard errors for HR laroup $x$ triall 
Increase venous return to the heart and are responsible for the rap1d Increase in SV and $\dot{Q}$.

The subjects in thls study were performing at $20 \% \mathrm{MVC}$, so the $\mathrm{HR}$ response was slight. During dynamlc work, the HR typlcally increases IInearly with Increasing workload and may reach maximal levels shortly before exhaustion occurs (Astrand Rodahl, 1977). The oubjects in this study were working at only $30 \mathrm{x} \dot{\mathrm{vO}}_{2} \mathrm{max}, \mathrm{so}$ only small increases were observed in HR response. The metabolic demand of the large muscle mass used In walking at $30 \% \mathrm{~V}_{2} \mathrm{max}$ would clearly be much greater than that required to hold a static contraction of a small muscle group at $20 \%$ MVC. Th1s, rather than differences in vagal withdrawal and/or oympathet Ic stimulation, probably constitutes the primary cause of observed differences, although the other factors mentioned may contribute.

Heart rates for combination work were signiflcantly higher than for either static or dynamic work alone. Th1s is in agreement with Jackson et al. (1973) and Sanchez et al. (1979), However, K1lbom \& Persson (1981) reported that at comblnation work above $95 \% \mathrm{VO}_{2} \max$ the HR response was unaffected by the atat1c component to a near-maximal Bympathetic activation. At levels less than $957 \dot{\mathrm{v}}_{2}$ max combination work does produce an additive atress on the cardiovascular aystem, which was evidenced In the present atudy. That the atress is additive does not mean that HR response to comblnation work could be predicted by adding increments above resting level from the other two bouts. There are complex Interactions among neural and metabolic control mechanioms for comblnation work which were not investigated in this atudy, and constitute a challenge for further regearch. 
No significant differences in HR occurred among the 3 groups, Indlcating that aeroblc fitness probably does not affect the degree to which a person responds to the three experimental treatments (FIgure 1). It has been clearly eatablished that $\mathrm{HR}$ responses to absolute levels of work are Inversely related to fitness level (clausen, 1976), but apparently in exerclse relative to individual capacities, responses are unrelated to aeroblc fitness. Use of absolute loads would certainly elicit significant group differences in dynamic work, but responses to static and combined exercise would be of interest. Another point that should be examined is the degree to which similar results would be obtained if higher relative loads were used.

\section{Blood Pressure}

Systolic blood pressure was significantly ( $p<.05)$ higher for all groups during combination work (FIgure 2). This elevation is a result of an Increased cardiac output that must be moved into the arterial tree against a significantly greater peripheral resistance. Registance to blood flow occurs locally when static contractions cause a mechanical hindrance to flow by higher Intramuscular pressures (Asmussen, 1981). In addition, a general vasoconstriction occurs in inactive tissues durIng dynamic work (LInd KcNicol, 1967a; Perez-Gonzalez, 1981). These factors interact to necessitate a higher driving force, the perfusion pressure.

No significant differences were found between the SBP responses, to static and dynamic work (FIgure 2). The 1ight atatic contractions (20\% MVC) caused only slight Increases in HR (12 beats.min ${ }^{-1}$ ) and $\dot{Q}$, and required only mild perfusion pressures to overcome intramuscular 


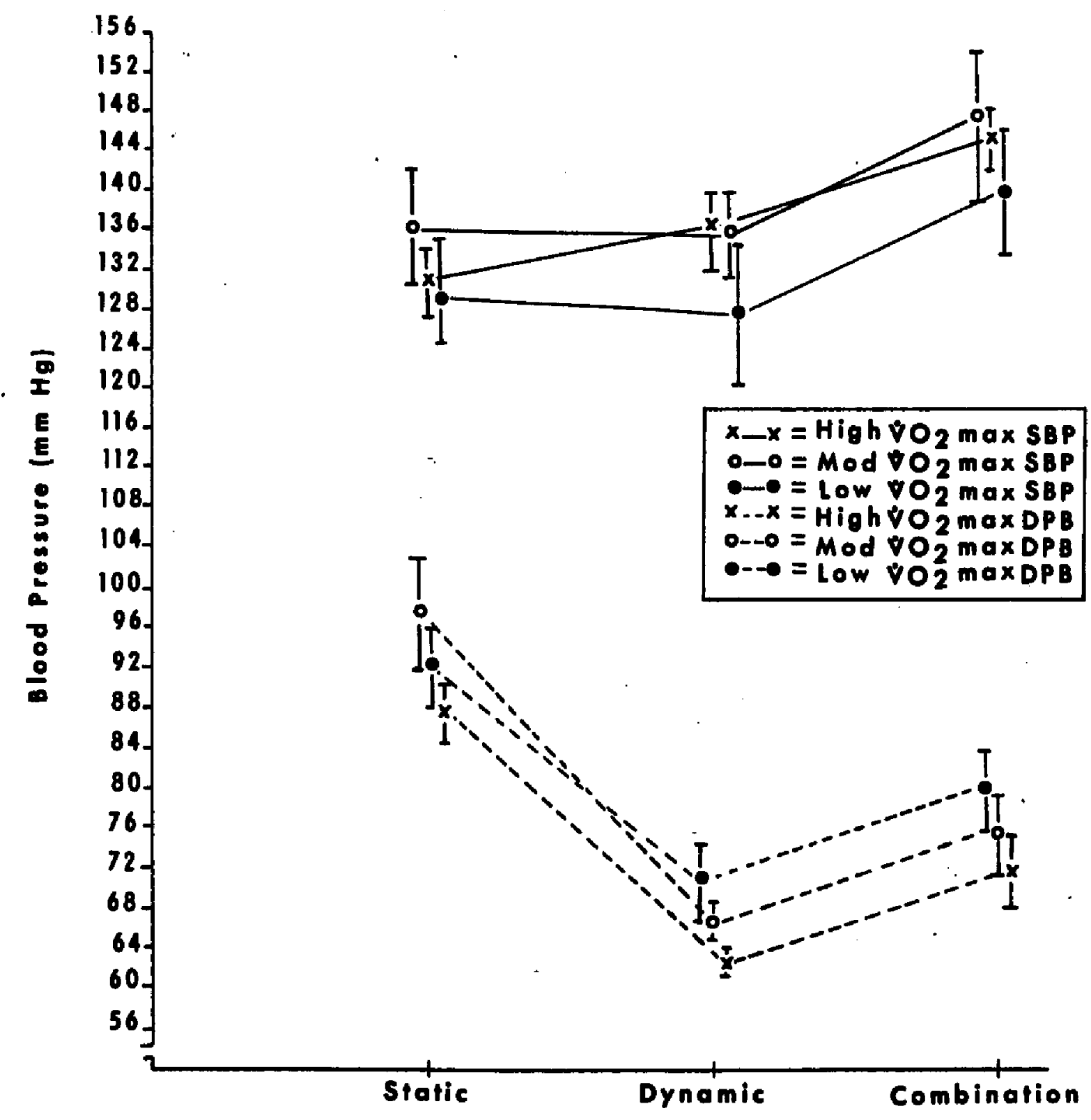

TYPE OF WORK

Figure 2. Means and standard erroris for systolic and diastolic blood pressure (group $x$ trial). . 
tenstons. Simtlerly, the dynamic work wes mild ( $30 \% \dot{v}_{2}$ max) whtch did not Increase HR substantlally $\left(34\right.$ beats.min $\left.{ }^{-1}\right)$ over rest. EvIdently, the lower HR with the greater peripheral resigtance was equivalent to the slightly higher $\mathrm{HR}$ and lower resiatance In terms of demands for perfusion pressure,

No significant group differences $(p<.05)$ in SBP responses were evident, Indicating that aeroblc fitness level does not alter the SBP response to the three types of work examined. This is in contrast to 11terature reporting that SBP is lowered at rest and during exercise following aeroblc training (Frlck et al., 1963; Montoye et al., 1972). One explanation for this difference might be that the use of relative rather than absolute loading did not significantly stress the subfects' pressure regulating mechanisms to cause differences at these low work levels. It would be of Interest to observe the affect of absolute loads on SBP under these three experimental conditions.

The dlastolic blood pressure for all groups was most elevated during static work (FIgure 2), In agreement with the 11terature (Tuttle \& Horvath, 1957; Whipp \& Davis, 1970). Static work increases DBP as a result of the Increases in $B R$ and $\dot{Q}$ which provide a greater perfusion pressure. This compensates for the increased peripheral resistance caused by compression of blood vessels (Lind et al., 1964). Dlastolic blood pressure was significantly lowered (p<.05) durting dynamic work compared to static work (FIgure 2). This is characteristic of this type of exercise and reflects the generalized vasodilation occurring In the active tissue along with removal of the mechanical obstruction caused by high intramuscular pressures in static work. 
During combination work the DBP was significantly increased above that found during dynamic work, but was at1ll significantly lower than that measured during static work. Active tissue vasodilation from the dynamic component of combination work may account for this reduced response. During dynamic work, the main determinants of the BP response are $\dot{Q}$ and peripheral reslstance. Normally, SBP and mean arterial pressure Increase when $\dot{Q}$ increases in response to a rise in HR. During this response, vasodilation in the active muscles and vasoconstriction in the Inactive reglons occur, controling changes in DBP and SBP. However, durIng combInation work the normsl balance between vasoconstriction and vasodilation is upset by the static component. Staunton et al. (1964) postulated that the diastollc pressure reflex operated such that perfusion pressure progressively Increased as blood flow became inadequate for metabolic requirements or for the removal of metabolites. Also, with atatic contractions, hindrance to blood flow occurs by the increased peripheral resistance and DBP increases.

No significant group differences $(\mathrm{p}<.05)$ were found, suggesting that aerob1c fitness does not affect DBP response to static, dynamic, or combination work, at least when the work bouts are set as percentages of maximum capacities. The question remains as to the responses to absolute loading at varfous levels of work.

\section{Presaure Rate Product}

Pressure rate product (SBP $\times \mathrm{HR} / 100)$ results for static, dynamic, and combination work were all aignificantly different $(\mathrm{p}<.05)$ (Figure 3). The PRP for all groups Increased sharply from static to dynamic work and from dynamic to comblnation work. Because PRP is directly 


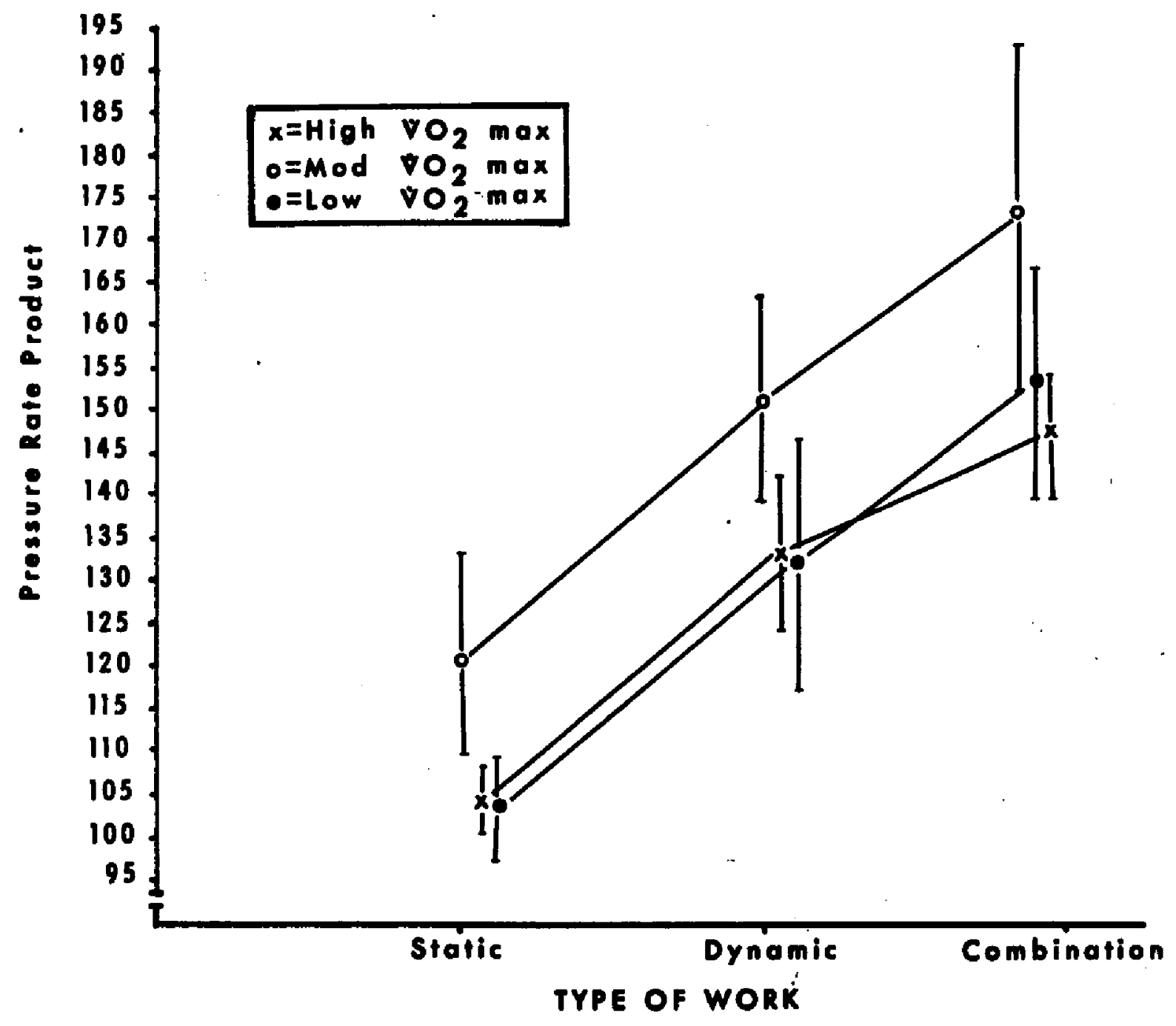

Figure 3. Means and standard errors of maximum pressure rate products (group $x$ irial). 
related to oxygen consumption by the heart, this Indicated that the myocardial oxygen demands were greatest during comblnation work and least during static work.

These findings are in agreement with those of Baisaly et al. (1974), Jackson et al. (1973), Lind McNlcol (1967a), and Robinson (1967) who reported that combination work had a higher physiological cost (BR and $\mathrm{O}_{2}$ uptake) than elther static or dynamic work alone. The cardlovascular aystem responds with an Increase in SBP and HR which in turn results in a significantly increased PRP.

With algnificantly higher SBP and AR In combination work, it was Inevitable that the higher PRP for that type of work should occur, PRP being computed by SBP $x$ HR +100 . Also, because SBP for static and dynamic work was similar, PRP for these conditions reflected olgnificant HR differences. The Importance of using PRP lies in 1ts being a much more valid predictor than HR or SBP alone of myocardial demand and insufficlency of oxygen. The large and olgnificant differences reflect a critical point, that, with respect to this indicator of myocardial need for oxygen, combination work tr1ggers significant and meaningful Increments in PRP above baselines set by elther static work or dynamic work alone. It 18 emphasized that this is true for 11ght work combinat1ons; the occurrence of "alrport angina" under more severe conditions 1s understandable. In addition, myocardial supply and demand are also a function of relative fitness; what might be an acceptable PRP and oxygen demand for the fit heart might be deadly to one who ouffers from some pathological condition.

Onexpectedly, there were no significant differences between groups, suggesting that aeroblc capacity does not affect the PRP response to 
work In standardized work relative to Individual maxima. Th1s is contrary to the findings of Boyer (1972), Buskirk (1973), Frick (1968), and Frick et al. (1963) who reported that PRP was lower In more active persons and could be lowered by aeroblc training. The obvious explanation for this discrepancy is found in consideration of the differences In responses to absolute and relative loads.

$\underline{\mathrm{V}_{2}}$ Max

Significant differences in $\grave{\mathrm{V}}_{2}$ max appeared between groups simply as a condition of subject assignment and experimental design. There were no olgnificant differences $(\mathrm{p}<.05)$ In $\dot{\mathrm{V}}_{2}$ max between the first test (dynamic work only) and the second test (dynamic plus otatic work) (Table 2). The fact that these means would be significantly different If considered at an alpha of .20 may justify further Investigation on the effects of static contractions on $\dot{\mathrm{V}}_{2}$ max. Certainly, both practical and theoretical questions arlse in examining the relationship.

It would appear that when static and dynamic work are combined, an Increase In $\dot{\mathrm{V}}_{2} \max$ should occur due to the Increased blood flow to the active muscles caused by the higher perfusion pressure elicited by the static component. However, the results in this study did not support this theory. The type and intensity employed in confunction with dynamic work did not significantly affect $\dot{\mathrm{vO}}_{2}$ max.

R11bom \& Persson (1981) evaluated the responses to combined static handgrip at $20 \%$ MVC and dynamic leg exercise at levels of $25 \%, 45 \%$, and 957 of $\dot{\mathrm{V}}_{2}$ max. Their results Indicated that, as maximal oxygen uptake was approached, the $\mathrm{BR}$ and $\mathrm{BP}$ response to handgrIp contractions was progressively 1 ess marked. At $95 \%$ of $\dot{\mathrm{V}}_{2} \max$, the systolic BP response 
Table 2

Means and Standard Deviations for

$\dot{\mathrm{v}}_{2} \max \left(\mathrm{ml} \cdot \mathrm{kg}^{-1} \cdot \mathrm{mIn}^{-1}\right)$

\begin{tabular}{lccc}
\hline Work Type & $\mathrm{High}_{2} \max$ & $\mathrm{Mod}_{2} \mathrm{VO}_{2} \max$ & $\mathrm{Low}_{2} \mathrm{VO}_{2} \max$ \\
\hline Dynamic & $64 \pm 3$ & $55 \pm 1$ & $47 \pm 5$ \\
Dynamic + static & $65 \pm 3$ & $56 \pm 2$ & $47 \pm 7$ \\
\hline
\end{tabular}


to handgrlp was abolished probably as a result of a competitive use of the same pressor response mechanism by the dynamic work, and because the vasoregulatory mechanisms in the leg muscles counterbalanced the rise in $\mathrm{BP}$.

This explanation could well be the reason that there was no significant increase in $\dot{\mathrm{VO}}_{2}$ max in this study. Because the subjects did not begin their static contraction until they were at over $90 \% \mathrm{VO}_{2}$ max, the potential additive BP response from the atatic work was abolished, and the Increase in perfusion pressure which should have enhanced oxygen delivery to the muscles was not present. Possibly, had the subjects performed the static contraction at lower percentages of $\dot{\mathrm{V}}_{2} \max$, significant differences might have been observed. However, It was the purpose of this study to evaluate the effects of static contractions during maximal work to determine whether any increases in $\mathrm{vO}_{2} \max$ would occur which might have Implications for athletic performance.

\section{Summary and Conclusions}

The results Indicate that aerobic fitness level does not affect the HR, SBP, DBP, or PRP response to work at $207 \mathrm{MVC}$, dynamic work at $30 \% \dot{\mathrm{v}}_{2} \mathrm{max}$, or to a combination of the atatic and dynamic work. Furthermore, $\dot{\mathrm{V}}_{2}$ max was not Increased by the addition of static work during a maximal dynamic test. However, static, dynamic, and combinatIon work did have significant effects on HR, SBP, DBP, and PRP. Heart rate and PRP were highest during comblnation work and lowest during , static work. Systolic and dlastolic blood pressure were highest during combination and static work, respectively, while DBP was lowest during dynamic work. No differences in SBP were observed between static and dynamic work. 
Although the results did not support the hypotheses that high $\dot{\mathrm{V}}_{2} \max$ aubjects wIll have reduced $\mathrm{BR}, \mathrm{SBP}, \mathrm{DBP}$, and PRP than moderate or low $\mathrm{V}_{2} \max$ subjects, they did support the literature regarding the effects of static, dynamic, and combination work on HR, SBP, DBP, and PRP. Stat1c work was shown to elicit the highest increases in DBP and combination work caused the hIghest Increases In SBP, HR, and PRP. These results are Important, especially to persons having cardiovascular problems such as hypertension or angina. A knowledge of the effects of static and combination work on the cardiovascular syotem would enable these persons to 1imit their activities to levels which do not result in dangerous cardlovascular changes.

This study has presented a number of areas in which additional research should be pursued. A question remains as to the responses to absolute loading at varfous levels of work. The results suggest that, at absolute loads, differences in HR, SBP, DBP, and PRP might appear In subjects having different $\dot{\mathrm{v}}_{2}$ max levels. Furthermore, the differences In $\mathrm{VO}_{2} \max$ levels between dynamlc work and dynamlc plus static work justify further Investigation using static contractions at lower percentages of $\dot{\mathrm{V}}_{2}$ max. The possibility at1ll remains that a otatic contraction might benefit performance by Increasing $\dot{\mathrm{v}}_{2} \max$ if the static contraction 18 performed at lower levels of $\dot{\mathrm{v}}_{2}$ max than were used in this study. 
Alam, M., \& Smirk, F. H. Observations in man upon a blood pressure ralsing reflex arlsing from the voluntary miscles. Journal of Phystology, 1937, 89(4), 372-383.

Alam, M., Smirk, F. H. Observations in man on a pulse-accelerating reflex from the voluntary muscles of the legs. Journal of Physiology, 1938, 92, 167-177.

Asmussen, E. Simflarities and dissimilaritles between static and dynamic exerc1se. Circulat Ion Research, 1981, 48, 1-10. (Monograph)

Asmussen, E., \& Hansen, E. Ueber den elnfluss stat 1scher muskelarbe1t auf atmung and kreiglauf. Skand Inavian Archives of Physiologica, 1938, 78, 283. (Lind, A. R., Taylor, S. H., Humphreys, P. W., Kennelly, B. M., Donald, R. W. The circulatory effects of oustained voluntary muscle contractions. C1intcal Sclence, 1964, 27, 229-244.)

Astrand, P., Cuddy, T. E., Saltin, B., S Stenberg, J. Cardiac output during submeximal and maximal work. Journal of Applied Physiology, $1964, \underline{19}(2), 268-274$.

Astrand, P., Rodahl, K. Textbook of work phystology (2nd ed.). New York: McGraw-H111, 1977.

Barcroft, H., \& Millen, J. L. E. The blood flow through muscle during sugta1ned contraction. Journal of Physiology, 1939, 97, 17-31.

Boyer, J. M. Effects of chronic exercise on cardlovascular function. Physical Fitness Research D1gest, 1972, 2(3), President's Counc 11 on Physical Fitness and Sports. Washington, D.C. 
Boyer, J. L., \& Rasch, F. W. Exercise therapy in hypertensive men. Journal of the American Medical Assoclation, 1970, 211, 1668-1671. (Clark, H. H. (Bd.). Physical Fitness Research Digest, 1972, 2(4), President's Counc Il on Physical Fitness and Sports. Washington, D. C.)

Bruce, R. A., LInd, A. R., Franklin, D., Muir, A. L., MacDonald, H. R., McNicol, G. W., Donald, K. W. The effects of digoxin on fatiguing static and dynamic exercise in man. Clinical Sclence, 1968, 34 , 29-42.

Buck, J. A., Amundsen, L. R., \& Nielsen, D. H. Systolic blood pressure responses during 1sometric contractions of large and small muscle 8roups. Medicine and Sclence In Sports and Exerclee, 1980, 12(3), 145-147.

Buskirk, E. R. Cardlovascular adaptation to physical effort in healthy men. In J. Naughton \& H. R. Hellergtein (Eds.), Exerclse testing and exerclse training In coronary heart disease. New York: Academic Press, 1973.

Clarke, H. H. (Ed.). Physical Fitness Research Digest, 1972, 2(4), President's Council on Physical Fitness and Sports. Washington, D.C. Clarke, R. S. J., Hellon, R. F., \& Lind, A. R. The duration of gustained contractions of the buman forearm at different muscle temperatures. Journal of Physiology, 1958, 143, 454-473. 
Clausen, J. P. Circulatory adjustments to dypamic exercise and effect of physical training in normal subjects and in patients with coronary artery disease. Progress in Cardlovascular Diseases, $1976,18(6), 459-495$.

deVries, H. A. Physlology of exerc1se, (3rd ed.). Dubuque:

พ. C. Brown, 1980.

Donald, K. W., Lind, A. R., McNicol, G. W., Humphreys, P. W. Taylor, S. H., Staunton, H. P. Cardlovascular responses to sustained (stat1c) contractions. Circulation Research, 1967 , 20-21 (Supp1), 15-30.

Ekblom, B. Effect of physical training on oxygen transport system in man. Acta Physiologica Scandinavica, 1969, 328, 9-44.

E1lestad, M. H., Allen, W., Wan, C. K., Kemp, G. L. Maximal treadmill atress testing for cardlovascular evaluation. Circulation, $1969,39,518$.

Freund, P. R., Hobbs, S. F., Rowell, L. B. Card Lovascular responses to muscle 1schemia in man - dependency on muscle mass. Journal of Applied Physlology, 1978, 45(5), 762-767.

Freyschuse, U. Card Lovascular adfustment to somatomotor act Ivation. Acta Physiologica Scandinavica, 1970, Suppl 343, 1-60.

Frick, H. H. Coronary Implications of hemodynamic changes caused by physical training. Amertean Journal of Cardiology, 1968, 22, 417-422. Frick, M. H., Konttinen, A., Sarajas, S. S. H. Effects of physical training on circulation at rest and during exercise. American Journal of Cardiology, 1963, 12, 142-147. 
Froelicher, V. F. The hemodynamic effects of physical conditioning in healthy young, middle aged Individuals, and in coronary heart disease patlents. In J. Naughton \& H. K. Hellersteln (Eds.), Exerc1se testing and exerclse training in coronary heart disease. New York: Academic Presa, 1973.

Gaskell, W. H. On the changes of the blood stream in muscles through et inulation of their nerves. Journal of Anatomy, 1877, 11, 360. (Donald, K. W., Lind, A. R., McNicol, G. W., Humphreys, P. W., Taylor, S. H. Staunton, H. P. Cardfovascular responses to sustained (atatic) contractions. Clrculat Ion Regearch, 1967, 20-21 (Supp1), 15-30.)

Halssly, J. C., Messin, R., Degre, S., Vandermoten, P., Demaret, B., \& Denolin, H. Comparative responses to 1sometric (static) and dynamlc exerctse tests in coronary disease. American Journal of Card1ology, 1974, 33, 791-796.

Helfant, H., DeVIlla, M. A., Meister, S. G. Effect of sustained Isometric handgrip exercise on left ventricular performance. Circulation, 1971, 44, 982-993.

Hellebrandt, F. A., Houtz, S. J., Hockman, D. E., \& Partridge, M. J. Physiological effects of almultaneous static and dynamic exercise. American Journal of Physical Medicine, 1956, 35(2), 106-117. Humphreys, P. W., \& LInd, A. R. The blood flow through active and Inactive muscles of the forearm during surstained hand-grip contractions. Journal of Phys1ology, 1963, 166, 120-135. 
Jackson, D. H., Reeves, T. J., Sheffield, L. T., \& Burdeshaw, J. Isometric effects on treadmill exercise response in healthy young men. American Journal of Cardtology, 1973, 31, 344-350.

Johnson, B. L., \& Nelson, J. K. Effect of different motivational techniques during training and In testing upon strength performance. Research Quarter1y, 1967, 38(4), 630-636.

Kilbom, A. \& Persson, J. Cardiovascular response to combined dynamic and static exercise. C1rculation Research, 1981, 48, 93-97. (Monograph)

Kivowitz, C., Parmley, W. W., Donoso, R., Marcus, H., Ganz, W. \& Swan, H. J. Bffects of 1sometric exercloe on cardiac performance - the grip teat. Circulation, 1971, 44, 994-1002.

Knox, J. A. C. The effect of the static and of the dynamic components of muscular effort on the heart rate. Journal of Physlology, 1951, 113, 36-42.

Kro11, W. Isometric fatigue curves under varied intertrial recuperation per 1ods. Research Quarterly, 1968, 39(1), 106-115.

Kuhlemeler, K. V. Card lovascular responses and regulation during static and dynamic work, singly and In combination (Doctoral dissertation, University of Minnesota, 1972). Dissertation Abstracts International, 1973, 34, 73-i0593. (Untversity Microfilms No. 73-10, 593)

Lar son, L. A. (Bd.). Fitneas, health, and work capacity. New York: Mackillan Publiohing, 1974.

Lind, A. R. Mucle fatigue and recovery from fatigue Induced by oustained contract Ions. Journal of Physlology, 1959, 127, 162-171. 
Lind, A. R. Cardovascular responses to static exercise (1sometr1c8, anyone?). C1rculation, 1970, 41(2), 173-176. (Editorial)

Lind, A. R., \& McNicol, G. W. Cardiovascular responses to static and dynamic exerclie. Ergonomics, 1965, 8(3), 379. (Abstract)

Lind, A. R., McNicol, G. W. Circulatory responses to sustained hand-grip contractions performed during other exercise, both rhythic and static. Journal of Physiology, 1967, 192, 595-607. (a).

Lind, A. R., McNicol, G. W. Local and central circulatory responses to sustained contractions and the effect of free or restricted arterlal inflow on post-exerclse hyperaemia. Journal of Physiology, 1967, 192, 575-593. (b)

Lind, A. R., McNicol, G. W. Mucular factors which determine the cardfovascular responses to sustained and rhythmic exercise. Canadian Medical Assoclation Journal, 1967, 96, 706-713. (c)

Lind, A. R., McNIcol, G. W. Cardlovascular responses to holding and carrying welghts by hand and by shoulder harness. Journal of Applied Physiology, 1968, 25(3), 261-267.

LInd, A. R., Taylor, S. H., Humphreys, P. W., Kennelly, B. M., \& Donald, K. W. The circulatory effects of sustained voluntary muscle contraction. Clinical Sclence, 1964, 27, 229-244.

Lindhard, J. Untersuchungen uber statiache muskelarbeit. Skandinaylan Archtves of Physiologice, 1920, 40, 145. (Lind, A. R., Taylor, S. H., Humphreys, P. W., Kennelly, B. M., \& Donald, K. W. The clrculatory effects of oustained voluntary muscle contractions. Clinical Sclence, 1964, 27, 229-244.) 
MacDonald, H. R., Sapru, R. P., Taylor, S. H., \& Donald, R. W. Effect of Intravenous propranolol on the systemic circulatory response to sustained handgrip. American Journal of Cardiology, $1966,18,333-334$.

McDonald, D. A. Blood flow in artertes. London: Bdward Arnold, LTD. , 1960.

McCloskey, D. I., \& Streatfelld, R. A. Muscular reflex stimuli to the cardlovascular system during tsometric contractions of muscle groups of different mass. Journal of Physiology, 1975, 250, 431-441.

Montoye, H. J., Metzner, H. L., Keller, J. B., Johnson, B. C., \& Epstein, F. H. Habitual physical activity and blood pressure. Medicine and Sclence in Sporto, 1972, 4, 175-181.

Mundale, M. 0 . The relationship of Intermittent 1sometric exercise to fatigue of hand grip. Archives of Physical Medicine and Rehab111tation, $1970,51,532-539$.

Perez-Gonzalez, J. F. Factors determining the blood pressure responses to 1sometric exercise. Circulation Research, 1981, 48, 76-86. (Monograph)

Petro, J. R., Hollander, A. P., \& Bouman, L. N. Instantaneous cardiac acceleration In man Induced by a voluntary muscle contraction. Journal of Applied Physiology, 1970, 29(6), 794-798.

Petrofaky, J. S., \& Lind, A. R. Metabolic, cardlovascular, and respiratory factors in the development of fatigue in lifting tasks. Journal of Applied Phystology, 1978, 45(1), 64-68. 
Quarry, V. M., \& Spodick, D. H. Cardlac responses to Isometric exerclse - comparative effects with different postures and levels of exertion. Circulation, 1974, 49, 905-920.

Ramos, M. U., Yundale, M. O., Awad, E. A., Witsoe, D. A., Cole, T. M., Olson, M., \& Rottke, F. J. Cardlovascular effects of opread of excitation during prolonges 1sometric exercise. Archives of Physical Medicine and Rehabilitation, 1973, 54, 496-504.

Robinson, B. R. Relation of heart rate and systolic blood pressure to the onset of pain in angina pectoris. Circulation, 1967, 35, 1073-1083.

Rowell, L. B., Brenglemann, G. L., Blackmon, J. R., Bruce, R. A., \& Murray, J. A. Dieparities between aortic and peripheral pulse pressures Induced by upright exerclse and vasomotor changes In man. Circulat1on, 1968, 37, 954-964.

SaltIn, B., Blomqvist, G., \& Mitchell, J. H. Response to exercise after bed rest and after training. C1rculation, 1968, 38, Supp1 7 . Saltin, B., Mitchell, J. H., Schibye, B., \& Payne, F. C. Role of muscle mass in the cardiovascular response to lsometric contractions. Acta Phystologice Scandinavica, 1978, 101(1), 79A-80A. (Abstract)

Sanchez, J., Monod, H., \& Chabaud, F. Effects of dynamic, static and combined work on heart rate and oxygen consumption. Ergonomics, $1979, \underline{22}(8), 935-943$. 
Shepherd, J. T., Blomqvist, C. C., LInd, A. R., Mitchell, J. H., \& Saltin, B. Static (1sometric) exercise. Circulation Research, 1981, 48, 104-109. (Monograph)

Siegel, W., Blomqv1st, G., Mitchell, J. H. Effects of a quantitated physical training program on middle-aged sedentary men. Circulation, 1970, 41, 19-29.

Simonson, E. (Ed.). Physiology of work capac1ty and fat 1gue. Springf 1eld: Charles Thomas, 1971.

Start, R. B., Holmes, R. Local muscle endurance with open and occluded intramuscular circulation. Journal of Applied Physiology, $1963,18(4), 804-807$.

Staunton, H. P., Taylor, S. H., \& Donald, K. W. The effect of vascular occlusion on the pressor response to static muscular work. Clinical Sclence, 1964, 27, 283-291.

Stephens, J. A., Taylor, A. Fatigue of maintained voluntary muscle contraction in man. Journal of Physiology, 1972, 220, 1-18.

Strong, W. B., Miller, M. D., Striplin, M., \& Salehbha1, M. Blood pressure response to isometric and dynamic exercise in healthy black children. American Journal of Diseases of Children, $1978,132,587-591$.

Thompson, C. W. Some physlologic effects of loometric and 1sotonic work in man. Research Quarterly, 1954, 25, 477-482. Tuttle, พ. พ., \& Horvath, S. M. Comparison of effects of static and dynamic work on blood preseure and heart rate. Journal of Applied Phystology, 1957, 10(2), 294-296. 
Wahren, J., Bygdeman, S. Onset of angina pectoris in relation to circulatory adaptation during arm and $1 \mathrm{eg}$ exercise. Circulation, $1971,44,432-441$.

Whipp, B. J., Davis, J. A. Peripheral chemoreceptors and exercise hyperpnea. Medicine and Sclence in Sports, 1970, 11(2), 204-212.

Whitney, R. J. The measurement of volume changes in human 1 Imbs. Journal of Physilogy, 1953, 121, 1-27.

Wiley, R. L., \& Lind, A. R. Respiratory responses to simultaneous static and rhythic exercises in humans. Clintcal Sclence and Molecular Medicine, 1975, 49, 427-432.

Wilmore, J. H., Norton, A. C. The heart and lungs at work. Beckman: 1975. 
AP PENDIX A 
Table Al

Dependent Variables by Subject

Static and Dynamic Work

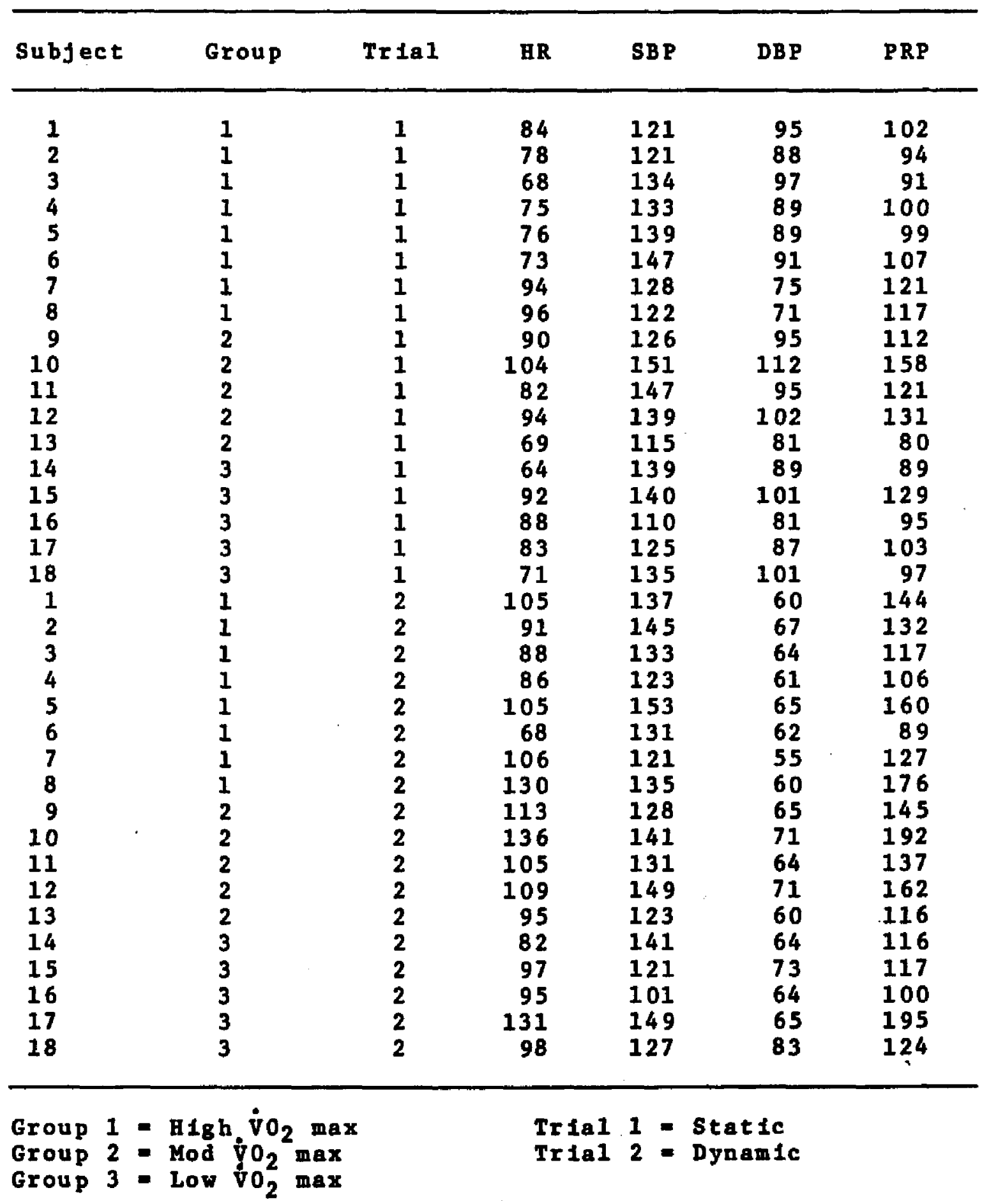


Table A2

Dependent Varlables by subject

CombInation Work

\begin{tabular}{rrrrrrr}
\hline Subject & Group & Tria1 & HR & SBP & DBP & PRP \\
\hline 1 & 1 & 3 & 100 & 135 & 77 & 134 \\
2 & 1 & 3 & 89 & 144 & 67 & 129 \\
3 & 1 & 3 & 91 & 125 & 75 & 114 \\
4 & 1 & 3 & 107 & 152 & 59 & 163 \\
5 & 1 & 3 & 105 & 156 & 78 & 164 \\
6 & 1 & 3 & 85 & 155 & 87 & 131 \\
7 & 1 & 3 & 111 & 149 & 61 & 162 \\
8 & 1 & 3 & 124 & 139 & 69 & 172 \\
9 & 2 & 3 & 114 & 147 & 71 & 167 \\
10 & 2 & 3 & 150 & 164 & 81 & 245 \\
11 & 2 & 3 & 110 & 146 & 86 & 160 \\
12 & 2 & 3 & 113 & 156 & 73 & 176 \\
13 & 2 & 3 & 97 & 116 & 65 & 113 \\
14 & 3 & 3 & 86 & 152 & 78 & 131 \\
15 & 3 & 3 & 104 & 141 & 83 & 147 \\
16 & 3 & 3 & 115 & 117 & 65 & 134 \\
17 & 3 & 3 & 138 & 153 & 75 & 212 \\
18 & 3 & 3 & 103 & 134 & 95 & 138 \\
\hline
\end{tabular}

Group $1=\mathrm{H} I \mathrm{gh}, \dot{\mathrm{VO}}_{2} \max$

Trial $3=$ Combination

Group $2=\operatorname{Mod} \mathrm{VO}_{2} \max$

Group $3=$ Low $\mathrm{VO}_{2} \max$ 
Table A3

Means and Standard Deviations

By Groups and Trialo

\begin{tabular}{|c|c|c|c|c|c|c|c|}
\hline$\frac{\text { Group }}{\mathrm{HIgh} \mathrm{VO}_{2} \max }$ & Varlable & $\begin{array}{l}s t \\
x\end{array}$ & $\begin{array}{r}\text { Ic } \\
\text { SD }\end{array}$ & $\begin{array}{c}\text { Dyn } \\
\mathbf{X}\end{array}$ & $\begin{array}{r}1 \mathbf{C} \\
\text { SD }\end{array}$ & \multicolumn{2}{|c|}{ Combination } \\
\hline & HR beats.min ${ }^{-1}$ & 81 & 10 & 97 & 18 & 101 & 13 \\
\hline & SBP mm $\mathrm{Hg}$ & 131 & 9 & 135 & 11 & 144 & 11 \\
\hline & DBP mm $\mathrm{Hg}$ & 87 & 9 & 62 & 4 & 72 & 9 \\
\hline & P RP & 104 & 11 & 132 & 28 & 146 & 21 \\
\hline Moderate $\mathrm{V}_{2}$ & $\max$ & & & & & & \\
\hline & HR beats.min-1 & 88 & 13 & 112 & 15 & 117 & 20 \\
\hline & SBP $\mathrm{mm} \mathrm{Hg}$ & 136 & 15 & 134 & 11 & 146 & 18 \\
\hline & DBP mm $\mathrm{Hg}$ & 97 & 11 & 66 & 5 & 75 & 8 \\
\hline & PRP & 120 & 29 & 151 & 29 & 172 & 48 \\
\hline & HR beato.m In-1 & 80 & 12 & 101 & 18 & 109 & 19 \\
\hline & SBP mm $\quad H_{g}$ & 130 & 13 & 128 & 19 & 139 & 15 \\
\hline & DBP mm $\mathbf{H g}$ & 92 & 9 & 70 & 8 & 79 & 11 \\
\hline & P RP & 102 & 16 & 130 & 37 & 152 & 34 \\
\hline
\end{tabular}


Table A4

Analysis of Varlance

for Heart Rate

\begin{tabular}{lrrr}
\hline Source & df & MS & F \\
\hline Group & 2 & 703.430 & 1.17 \\
Error A & 15 & 602.894 & \\
Trial & 2 & 3286.772 & $55.81 * *$ \\
Group*Trial & 4 & 45.457 & .77 \\
Error B & 30 & 58.889 & \\
Total & 53 & & \\
\hline ** P<.01 & & & \\
\hline
\end{tabular}

Duncan's Multiple Range Test ( $\underline{p}<.05)$

No signiflcant Group differences.

Static significantly different from Dynamic Dynamic significantly different from Combination Combination significantly different from Static 
TABLE A5

Analysis of Variance

for Systolic Blood Pressure

\begin{tabular}{lrrr}
\hline Source & df & MS & F \\
\hline Group & 2 & 158.422 & .44 \\
Error A & 15 & 362.794 & \\
Trial & 2 & 696.285 & $8.94 * \star$ \\
Group*Trial & 4 & 19.839 & .25 \\
Error B & 30 & 77.897 & \\
Total & 53 & & \\
\hline ** $\mathrm{P}<.01$ & & & \\
\hline
\end{tabular}

Duncan's Multiple Range Test (p<.05)

No significant Group differences.

Static significantly different from Combination Dynamic oignificantly different from Combination Statlc not algnificantly different from Dynamic 
Table A6

Analysts of Vartance

for Dlastolle Blood Presgure

\begin{tabular}{lrrr}
\hline Source & df & MS & I \\
\hline Group & 2 & 277.921 & 1.72 \\
Error A & 15 & 161.358 & \\
Trial & 2 & 2954.356 & $100.54 \star \star$ \\
Group*Trial & 4 & 34.353 & 1.17 \\
Error B & 30 & 29.384 & \\
Total & 53 & & \\
\hline ** pe.01 & & & \\
\hline
\end{tabular}

Duncan's Multiple Range Test (p <.05)

No significant Group difference.

Static significantly different from Dynamic Dynamic significantly different from Combination Combination oignificantly different from Static 
Table A7

Analysis of Vartance

for Pressure Rate Product

\begin{tabular}{lrrr}
\hline Source & df & MS & F \\
\hline Group & 2 & 2175.563 & 1.19 \\
Error A & 15 & 1824.495 & \\
Tria1 & 2 & 9989.843 & $33.14 * *$ \\
Group*Tr1a1 & 4 & 50.621 & .17 \\
Error B & 30 & 301.435 & \\
Total & 53 & & \\
\hline
\end{tabular}

** $\mathrm{p}<.01$

Duncan's Multiple Range Test $(\mathrm{g}<.05)$

No signiflcant Group difference.

Static oignificantly different from Dynamic Dynamic significantiy different from Combination Combination algnificantly different from Static 
Table A8

Analygis of Varlance

for $\dot{\mathrm{V}}_{2} \mathrm{Max}$

\begin{tabular}{lrrr}
\hline Source & df & MS & F \\
\hline Group & 2 & 960.159 & $37.19 * *$ \\
Error A & 15 & 25.820 & \\
Time & 1 & 6.953 & 2.05 \\
Group*T1me & 2 & .882 & .26 \\
Error B & 15 & 3.395 & \\
Total & 35 & & \\
\hline ** P<.01 & & & \\
\hline
\end{tabular}

Duncan's Multiple Range Test $(p<.05)$

Group 1 significantly different from Group 2

Group 2 significantly different from Group 3

Group 3 significantly different from Group 1

$\mathrm{VO}_{2} \max$ (dynamic) not significantly different

from $\mathrm{VO}_{2} \max$ (dynamic + stat $1 c$ ) 
Table A9

W1Iks' Lambda MANOVA

\begin{tabular}{|c|c|c|c|}
\hline Source & df & W11ks' Lambda & $\mathbf{F}$ \\
\hline Group & 2 & .562 & 1.45 \\
\hline Subject (Group) & 15 & & \\
\hline Trial & 2 & .046 & $34.04 * * *$ \\
\hline Group*Trial & 4 & .686 & .95 \\
\hline Error & 30 & & \\
\hline Total & 53 & & \\
\hline
\end{tabular}


VITA

John Francis Harper was born on September 27, 1951 in Florence, South Carolina. He was graduated from Frankfurt AmerIcan H1gh School In Frankfurt, Germany In 1969. He attended the University of South Carolina, Columbia, South Carolina, from 1969 to 1973 where he was graduated with a Bachelor of Arts Degree In Health and Physical Education,

Following graduation from the University of South Carolina, Dr. Harper accepted a graduate assistantship at the UnIversity of South Carolina, Columbla, South Carolina, and began working toward a Master of Arts in Teaching Degree. Dr, Harper accepted a position as a Teaching Assoctate at the University of South Carolina, Columbla, South Carolina in 1974 which delayed completion of his Master's Degree unt11 1975. During his three and one-half years as a Teaching Associate, Dr, Harper was lab director, ECG technictan, Instructor, and researcher.

Dr. Harper enrolled In the Doctor of Philosophy Degree program offered by the School of Health, Physical Education, Recreation, and Dance at Loulstana State Untversity in 1978. Prior to completion of this degree, Dr. Harper accepted a teaching position as Assistant Professor in exercise physlology In the Department of Health, Physical and Recreation Education at West Texas State University, Canyon, Texas. The Doctor of Phtlosophy Degree was awarded in the major area of . Exercise Physiology the Summer semester of 1982. 
Candidate: John Francis Harper

Major Field: HPERD (Exercise Physiology)

Title of Theis: Cardiovascular Responses in High, Moderate and Low Aerobic Capacity Males During Static and Dynamic Work

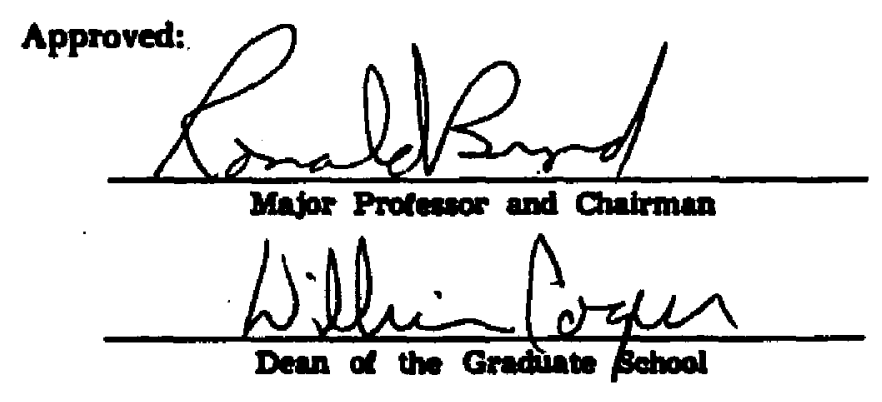

\section{EXAMINING COMMTTTEE:}

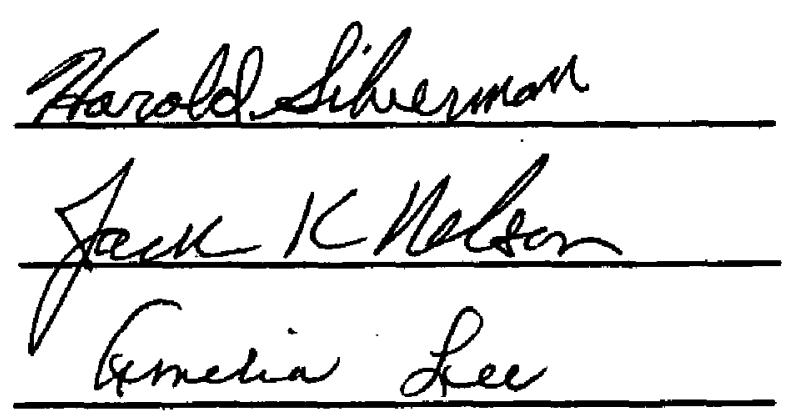

Enelgen Herser

Date of Examination:

Ju1y 19, 1982 